\title{
A novel multi-omics-based identification of symptoms, comorbid conditions, and possible long-term complications in COVID-19
}

Debmalya Barh $^{1 *}$, Sandeep Tiwari ${ }^{2}$, Bruno Silva Andrade ${ }^{3}$, Marianna E. Weener ${ }^{4}$, Aristóteles Góes-Neto $^{5}$, Vasco Azevedo ${ }^{2}$, Preetam Ghosh ${ }^{6}$, Nirmal Kumar Ganguly ${ }^{7}$

${ }^{1}$ Institute of Integrative Omics and Applied Biotechnology (IIOAB), Nonakuri, Purba Medinipur, WB, India.

${ }^{2}$ Laboratório de Genética Celular e Molecular, Departamento de Genética, Ecologia e Evolução, Instituto de Ciências Biológicas, Universidade Federal de Minas Gerais, Belo Horizonte, Minas Gerais, Brazil.

${ }^{3}$ Laboratório de Bioinformática e Química Computacional, Departamento de Ciências Biológicas, Universidade Estadual do Sudoeste da Bahia (UESB), Jequié, Bahia, 45205-490, Brazil.

${ }^{4}$ Clinical Research Center, Oftalmic, CRO, 119334 Bardina str.22/4 Moscow, Russia

${ }^{5}$ Laboratório de Biologia Molecular e Computacional de Fungos, Departamento de Microbiologia, Instituto de Ciências Biológicas, Universidade Federal de Minas Gerais (UFMG), Belo Horizonte, Minas Gerais, Brazil.

${ }^{6}$ Department of Computer Science, Virginia Commonwealth University, Richmond, VA, 23284, USA.

${ }^{7}$ National Institute of Immunology, New Delhi, India; Institute of Liver and Biliary Science, New Delhi, India; Policy Center for Biomedical Research, Translational Health Science \& Technology Institute, Faridabad, Haryana, India.

*Corresponding author: Email: dr.barh@gmail.com; Tel: +91-9449550032 
medRxiv preprint doi: https://doi.org/10.1101/2020.12.08.20245753; this version posted December 9, 2020. The copyright holder for this preprint (which was not certified by peer review) is the author/funder, who has granted medRxiv a license to display the preprint in It is made available under a CC-BY-NC-ND 4.0 International license .

\begin{abstract}
Till date the comprehensive clinical pictures, comorbid conditions, and long-term complications of COVID-19 are not known. Recently using a multi-omics-based strategy, we have predicted the drugs for COVID-19 management with $\sim 70 \%$ accuracy. Here, using a similar multi-omics-based bioinformatics approach and three-ways of analysis, we identified the symptoms, comorbid conditions, and short, mid and possible long-term complications of COVID-19 with 90\% precision. In our analysis (i) we identified 27 parent, 170 child, and 403 specific conditions associated with COVID-19. (ii) Among the specific conditions, 36 are viral and 53 short-term, 62 short to mid to long-term, 194 mid to long-term, and 57 are congenital conditions. (iii) At a cut off "count of occurrence" of 4 , we found $\sim 90 \%$ of the enriched conditions are associated with COVID19. (iv) Except the dry cough and loss of taste, all other COVID-19 associated mild and severe symptoms are enriched. (v) Cardiovascular, pulmonary, metabolic, musculoskeletal, neuropsychiatric, kidney, liver, and immune system disorders are found as top comorbid conditions. (vi) Specific diseases such as myocardial infarction, hypertension, COPD, lung injury, diabetes, cirrhosis, mood disorders, dementia, macular degeneration, chronic kidney disease, lupus, arthritis etc. along with several other diseases are also enriched as top candidates. (vii) Interestingly, many cancers and congenital disorders associated with COVID-19 severity are also identified. (viii) Arthritis, dermatomyositis, glioma, diabetes, psychiatric disorder, cardiovascular diseases having bidirectional relationship with COVID-19 are also found as top ranked conditions. Based on the accuracy ( 90\%) of this analysis, long presence of SARS-CoV-2 RNA in human, and our previously proposed "genetic remittance" assumption, we hypothesize that all the identified comorbid conditions including the short-long-mid and mid-long non-communicable diseases (NCDs) could also be long-term consequences in COVID-19 survivors and warrants long-term observational studies.
\end{abstract}

Key Words: COVID-19; SARS-CoV-2; proteome; transcriptome; interactome; comorbid conditions; long-term consequences; bioinformatics 
medRxiv preprint doi: https://doi.org/10.1101/2020.12.08.20245753; this version posted December 9,2020 . The copyright holder for this preprint (which was not certified by peer review) is the author/funder, who has granted medRxiv a license to display the preprint in

It is made available under a CC-BY-NC-ND 4.0 International license .

\section{INTRODUCTION}

Since the first report of SARS-CoV-2 infection between December 7, 2019 to December 12, 2019 from China [1-3], as of November 10, 2020, the virus has infected 49,727,316 people with $1,248,373$ deaths globally [4] .

Symptoms and comorbid conditions: Recent systematic reviews and meta-analysis based studies show that the most common short-term clinical symptoms in COVID-19 include fever (81.2\%$84.30 \%)$, cough $(58.5 \%-63.01 \%)$, fatigue (34.22\% - 38.5\%), dyspnea (26.1\% -37.16\%), Sputum $(25.8 \%)$, diarrhea $(11.47 \%)[5,6]$, myalgia $(7.7 \%)$, nasal congestion $(17 \%)$, abdominal pain $(2.4 \%)$, and emotional disturbances (15.9\%) [7]. However, in critical cases, the most common complications are acute respiratory distress syndrome (ARDS) (33.15\%), arrhythmia (16.64\%), acute cardiac injury (15.68\%), heart failure (11.50\%), and acute kidney injury (AKI) (9.87\%) [6]. Mortality and severity of COVID-19 is associated with various factors including gender (male, OR:1.60), behaviour (current smoker, OR:2.06), and existing several comorbid conditions [8].

The most important comorbid conditions are hypertension (OR:2.05), diabetes (OR:2.46), coronary heart diseases (OR:4.10), chronic kidney diseases (OR:4.06), and cancers (OR:2.28) [8]. A meta-analysis on underlying comorbid conditions in expired COVID-19 patients reveals hypertension is the most common comorbidity (46\%) in COVID-19 followed by diabetes (26\%), cardiovascular diseases (21\%), cerebrovascular disease (13\%), cancers (11\%), Lung disease (11\%), COPD (8\%), kidney disease (7\%), liver disease (3\%), and asthma (3\%) [9]. However, another metaanalysis suggests that asthma as a comorbid condition may not increase the mortality (OR: 0.96) [10]. Increased aspartate aminotransferase is associated with high severity and death from COVID19 (OR: 4.48) [11] and patients with cirrhosis showed worsening liver function and increased mortality [12]. Adverse drug-drug interactions may also potentially worsen the outcomes in comorbid conditions such as cardiometabolic diseases, chronic kidney disease, and COPD [13]. Other identified increased risk factors are polycystic ovarian disease, vitamin D deficiency, and obesity [14] and the list is long.

Clark et al. based on a Global Burden of Diseases, Injuries, and Risk Factors Study (GBD) 2017 has provided a list of comorbid conditions that may increase the risk of COVID-19 severity and fatality. The conditions include HIV/AIDS, tuberculosis, various cancers cardiovascular diseases, chronic respiratory diseases, chronic liver diseases, diabetes, chronic kidney diseases, chronic neurological disorders, and sickle cell disorders [15].

Mudatsir and colleagues in their systematic review and meta-analysis analysed 62 potential risk factors and have suggested that, severe COVID-19 is associated with more than 30 risk factors. These factors include comorbid conditions such as hypertension, diabetes, and chronic respiratory and cardiovascular diseases. In respect to symptoms, fatigue, dyspnea, increased respiratory rate, anorexia, and high systolic blood pressure are associated with severity of COVID-19. Apart from these, a higher level of blood troponin, aspartate aminotransferase, alanine aminotransferase, lactate dehydrogenase, procalcitonin, C-reactive protein, D-dimer, creatinine, ferritin, urea, interleukin, ESR and low levels of lymphocytes and haemoglobin also correlate with the disease severity from COVID-19 [16]. Further, decreased lymphocyte and platelet counts, and elevated D-dimer fibrin degradation are associated with poor prognosis [17]. 
medRxiv preprint doi: https://doi.org/10.1101/2020.12.08.20245753; this version posted December 9, 2020. The copyright holder for this preprint (which was not certified by peer review) is the author/funder, who has granted medRxiv a license to display the preprint in It is made available under a CC-BY-NC-ND 4.0 International license .

Long- haul COVID-19: Apart from the disease severity, recently long- haul COVID-19 is also reported frequently. Although most of the COVID-19 symptoms disappear within 21 days, nearly $10 \%$ of COVID-19 patients show symptoms even after three weeks, 5\% for eight weeks or more, and $2 \%$ suffer for nearly three months [18].

As discussed, several extra-pulmonary manifestations are found in COVID-19 [19]. Report suggests that the SARS-CoV-2 viral RNA remain present at low copies in various body samples of patients even after 75 days from the start of symptoms, suggesting the ability of this virus to provoke persistent infection and induce extra-pulmonary clinical symptoms [20]. It is reported that, only 10.8\% COVID-19 patients do not show any post-COVID manifestation after recovery from the disease [21]. However, several symptoms persist even after 3 months. The most common postCOVID symptoms are fatigue and dyspnea. Other frequent complications include joint and chest pain, myocardial inflammation, myocarditis, pulmonary dysfunction, pulmonary fibrosis, headache, vertigo, anosmia, ageusia, encephalitis, seizures, mood disorder and "brain fog",[22] lack of concentration, confusion, memory loss, dizziness, heart palpitations, tachycardia, and pain with deep breaths [23]. Low lung diffusion capacity is observed in $42 \%$ cases, besides also low exercise capacity (22\% cases), mental and/or cognitive function (36\% cases), fatigue (69\%-72.8\% cases) [21, 24], and headache (37.8\% cases) [25] among others. Other less frequent post-COVID symptoms so far reported are acalculous cholecystitis [26], dry eye disease [27], sudden onset sensorineural hearing loss [28], stroke, renal failure [21], autoimmune orthostatic hypoperfusion syndrome/painful small fiber neuropathy [29] etc. It is also found that all COVID-19 survivors are at risk of developing the long-term complications [23]. Current evidence suggests that COVID-19 patients are at higher risk in developing mental health problems that include depression, anxiety disorders, stress, panic attack, irrational anger, impulsivity, somatization disorder, sleep disorders, emotional disturbance, posttraumatic stress symptoms, and suicidal behaviour [30].

Long-term consequences of COVID-19: According to WHO, COVID-19 may increase the risk of developing long-term health issues related to cardiovascular systems, pulmonary system, brain and nervous system, musculoskeletal system, and mental health [31]. Apart from these, damage to kidney, liver and other endocrine system organs were also recently found in COVID-19 survivors [32]. Further, bidirectional relationship between COVID-19 and diabetes [33], psychiatric [34], and cardiovascular diseases [35] are also reported. Since the disease is just a year old, it is not yet well understood what could be the most common long-term health complications in COVID-19 survivors.

Based on this background, we hypothesize that, presence of comorbid conditions is associated with increased severity and fatality in COVID-19 and COVID-19 survivors may develop these comorbid conditions as long-term complications of COVID-19. So far, epidemiology, meta-analysis, case series, large cohort studies, review, GBD-2017, and longitudinal dynamics based approach have been used to identify the comorbid conditions and long-term complications in COVID-19. However, omics-based approach has not been used for prediction or identification of these conditions.

Recently, applying a multi-omics based bioinformatics analysis; we have predicted the SARS-CoV2 infection biology, the deregulated pathways, and potential drugs for COVID management with $70 \%$ precision [36]. Assuming that the diseases/ signs / symptoms associated with these upregulated multi-omics datasets are (i) related with COVID-19, (ii) contribute to COVID-19 associated comorbid conditions or risk factors, (iii) correlate with general or severe signs and symptoms of 
medRxiv preprint doi: https://doi.org/10.1101/2020.12.08.20245753; this version posted December 9, 2020. The copyright holder for this preprint (which was not certified by peer review) is the author/funder, who has granted medRxiv a license to display the preprint in

It is made available under a CC-BY-NC-ND 4.0 International license .

COVID-19, and (iv) these comorbid conditions could also be the long-term complications of COVID-19; in this analysis, we have used the same datasets (interactome, proteome, transcriptome, and bibliome) used in our previous report and a modified multi-omics approach [36] to predict the comorbid conditions, signs and symptoms, and the long-term complications in COVID-19.

\section{METHODS}

\section{Datasets}

Similar to our previous work [36], we have used the same five omics data sets: interactome data (I) of Gordon et al., 2020 [37] , proteome data (P) of Bojkova et al., 2020 [38] , transcriptome profiles (T-1 and T-2) of Blanco-Melo et al., 2020 [39] and Xiong et al., 2020 [40] along with the same bibliome data (B). Only the upregulated genes or proteins were considered for analysis from the datasets used in this work. Individual omics data (I, P, T-1, T-2, B) and their three combinations were used. The combinations were $\mathrm{P}+\mathrm{T}(\mathrm{P}+\mathrm{T}-1+\mathrm{T}-2), \mathrm{P}+\mathrm{T}+\mathrm{I}$, and $\mathrm{P}+\mathrm{T}+\mathrm{I}+\mathrm{B}$.

\section{Data analysis}

\section{Gene-set based disease enrichment}

Like our previous analysis, we have used the ToppFun and ToppGene modules of the ToppGene suite (https://toppgene.cchmc.org) with default parameters [41] for disease enrichment. In case of ToppGene module, the bibliome dataset (B) of 745 COVID-19 related genes were used as training set. The second enrichment tool used was Enrichr (https://amp.pharm.mssm.edu/Enrichr/) [42]. Six different databases integrated with the Enrichr [42] were selected to enrich the diseases or conditions. The GEO up, PheWeb, DisGeNET databases along with GWAS Catalog, OMIM Expanded, and Rare Diseases were used. The GWAS Catalogue, OMIM Expanded, and Rare Diseases based analysis were performed keeping in mind the "genetic predisposition" hypothesis (discussed later) to predict the possible genetic diseases associated with the gene sets used. Based on the P-value, Odds ratio, and combined score, the top 20 diseases from each analysis were then combined for a consolidated analysis.

\section{Consolidated disease analysis}

Contrary to our previous analytic approach [36], we have applied some additional considerations in this analysis. We have considered one of our previous hypotheses, i.e. "genetic remittance" [43]. According to this hypothesis, a virus or bacteria leaves a permanent signature inside host upon infection and that the host carries the signature for a long time. Therefore, pathways that are activated during the infection remains switched on for a considerable duration within the host and subsequently develop clinical symptoms in long term. The RNA of the SARS-CoV-2 remains active in the COVID-19 survivors for more than 75 days [20] and thus the virus can maintain the upregulation of these omics profile for long periods and as long-term consequences of it, the noncommunicable disease (NCD) pathways associated with these upregulated omics profile also remain active and subsequently will trigger the development of the clinical symptoms/phenotypes in long term.

In our gene-set-based disease enrichment, several unique terminologies for a disease or clinical symptom were enriched. Therefore, in the consolidated disease analysis, first we classified the enriched diseases or symptoms based on Disease Ontologies using Ontobee tool 
medRxiv preprint doi: https://doi.org/10.1101/2020.12.08.20245753; this version posted December 9, 2020. The copyright holder for this preprint (which was not certified by peer review) is the author/funder, who has granted medRxiv a license to display the preprint in

It is made available under a CC-BY-NC-ND 4.0 International license .

(http://www.ontobee.org) [44]. In this process, first we classified each disease or symptom under three relationships (parent - child - specific disease/symptom). For example, the "hypertensive disease" identified in gene-set-based disease enrichment is classified as cardiovascular system disease - vascular disease - hypertensive disease. Next, we grouped and counted each parent - child - specific disease/symptom based on parent, child, and specific disease/ symptom individually.

Further, based on the time or duration it takes to develop and present their clinical pictures in normal condition, each specific disease/ sign / symptom is further classified under short, short-mid, mid-long, short-mid-long, short-mid-long-genetic, mid-long-genetic, and congenital/genetic. For example, fever is classified under short and liver cirrhosis could be tagged with mid-long. Finally, based on the cumulative number of occurrence (the score), the diseases/conditions are ranked and the final results are considered based on this rank. A cut off 4 on the occurrence score was considered in most of the analysis to select the disease or symptoms. It should be noted that, a particular cumulative score for two or more different diseases are considered to have the same rank although they are listed one by one and diseases having same score have equal probability. The overall approach applied in our work is presented in Fig-1.

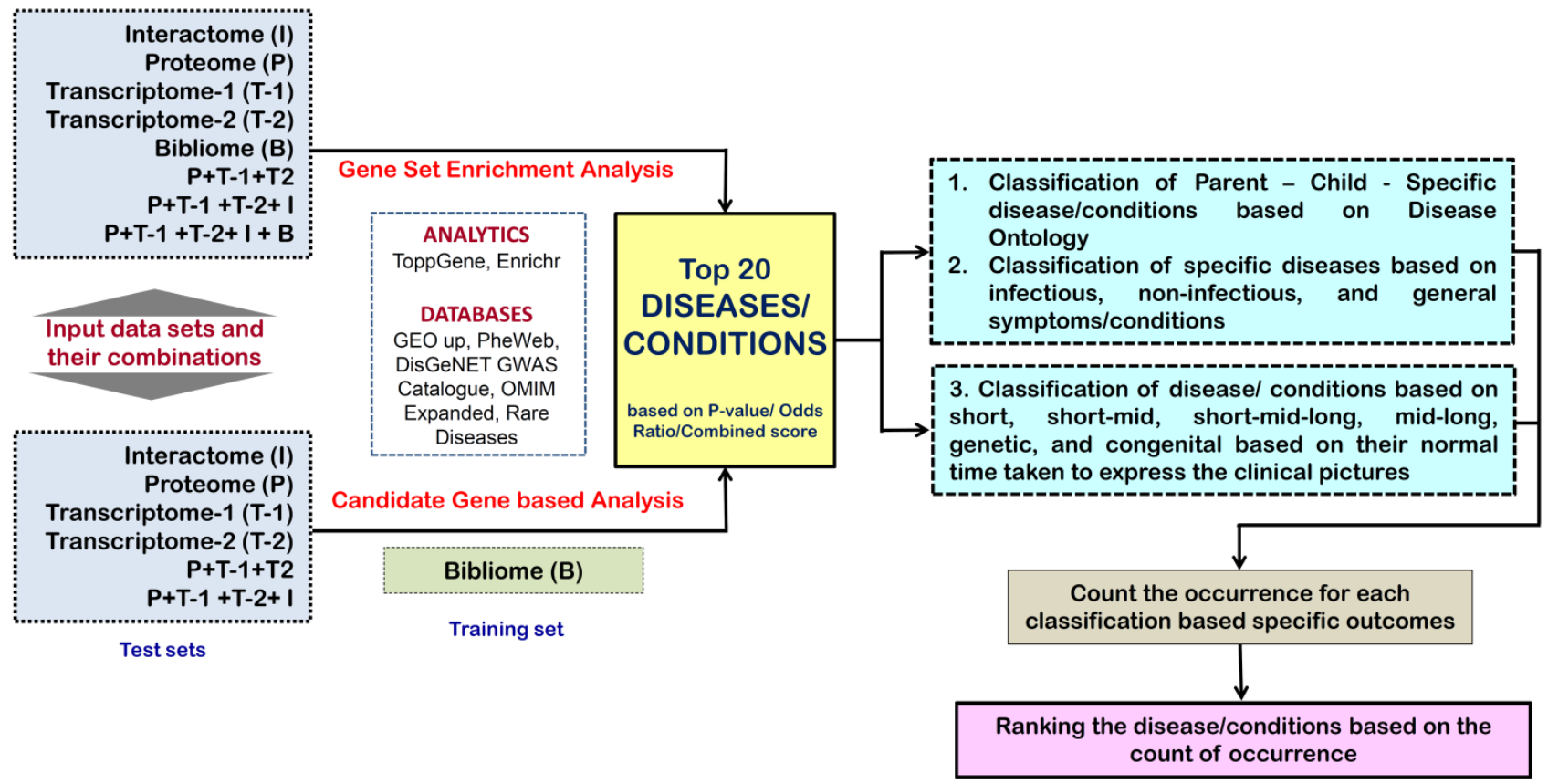

Fig.1: The flow diagram of the overall strategy applied in this analysis. For details, see the methods section.

\section{RESULTS AND DISCUSSION}

We generated 1210 classified parent - child - specific disease/symptom associations based on our top 20 enriched diseases for various omics datasets and their combinations using TopGene , Enricher, and Ontobee [44]. While we cleaned the data removing the duplicate of a specific disease or symptom and merged the similar diseases or symptoms to make the counting calculations, we obtained a dataset having 403 specific diseases or symptoms and used this dataset for further analysis. 
medRxiv preprint doi: https://doi.org/10.1101/2020.12.08.20245753; this version posted December 9, 2020. The copyright holder for this preprint (which was not certified by peer review) is the author/funder, who has granted medRxiv a license to display the preprint in

It is made available under a CC-BY-NC-ND 4.0 International license.

\section{COVID-19 associated parent disease or symptom groups}

We identified 27 parent diseases or symptoms based on our consolidated analysis without classifying them based on the time duration needed to develop these diseases or symptoms. Infectious disease came at Rank-1, neoplasm (Rank-2), abnormal sign or symptom (Rank-3), cardiovascular system disease (Rank-4), immune system disorder (Rank-5), nervous system disease (Rank-6), musculoskeletal system disease (Rank-7), metabolic disorder (Rank-8), and mental disorder (Rank-9). At Rank-10 two diseases, namely, congenital anomalies and respiratory system disease are enriched. Eye disease is Ranked at 11, gastrointestinal system disease (Rank-12), urinary system disease (Rank-13), skin disease (Rank-14), liver disease (Rank-15), hematopoietic system disease (Rank-16), sepsis (Rank-17), Response to drug (Rank-18), behaviour process (Rank19), and female reproductive system disease (Rank-19) constitute the top twenty disease classes (Fig-2A).

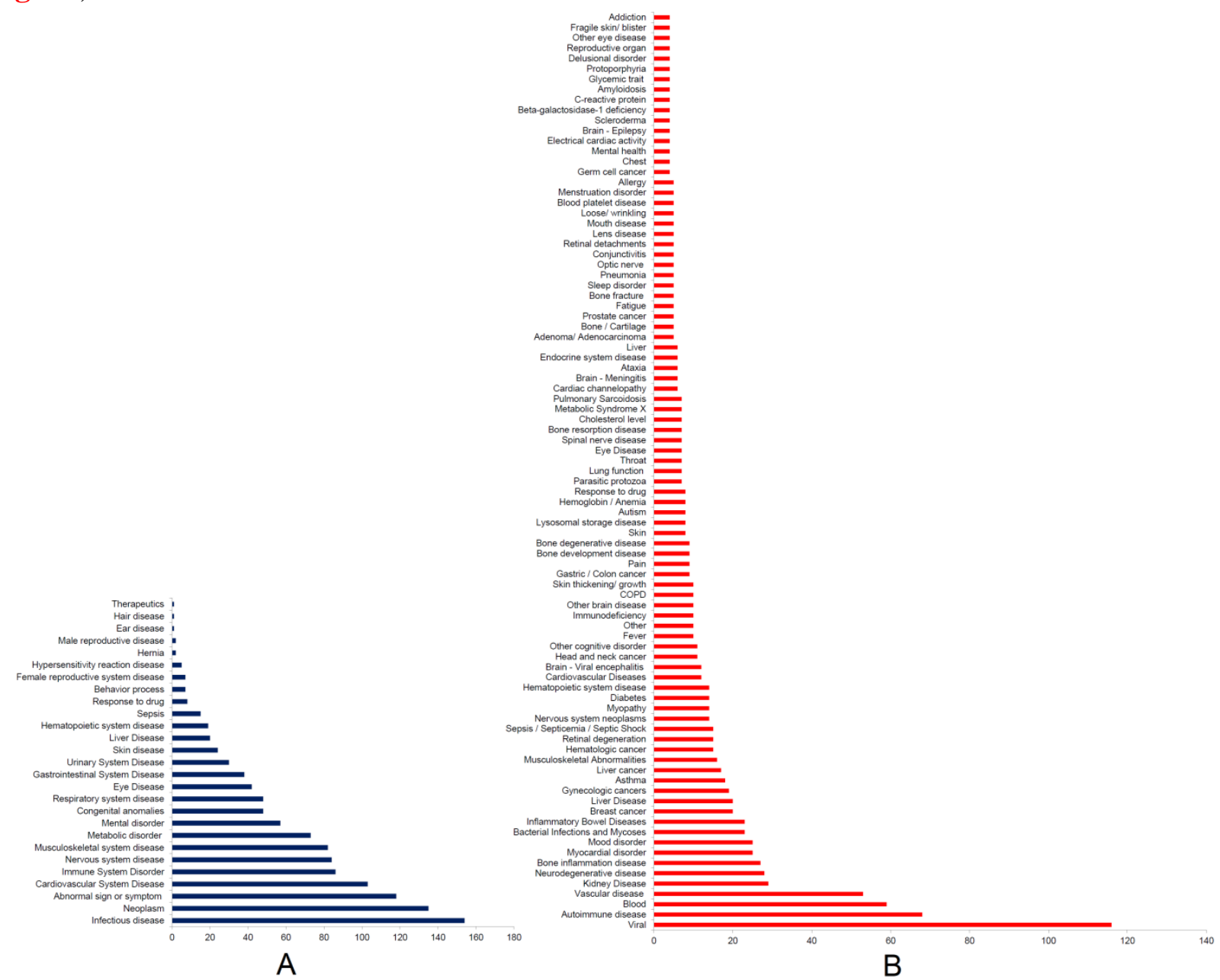

Fig-2: A) The top 27 parent diseases or symptoms as per the consolidated analysis. B) Top child diseases.

We found all most all the parent diseases as described by Clark et al. [15]. Our identified all the 27 parent diseases or symptoms are highly associated with COVID-19 which itself is a highly infectious disease [45]. Cancers [46], cardiovascular diseases [47, 48], autoimmune diseases [49, 50], metabolic disorders [51, 52], congenital heart disease [53, 54], respiratory system disease [48], gastrointestinal diseases [55], kidney diseases [56, 57], liver disease [58], hematopoietic system 
medRxiv preprint doi: https://doi.org/10.1101/2020.12.08.20245753; this version posted December 9, 2020. The copyright holder for this preprint (which was not certified by peer review) is the author/funder, who has granted medRxiv a license to display the preprint in

It is made available under a CC-BY-NC-ND 4.0 International license .

disease [59], sepsis or septicaemia [60] are the reported key comorbid conditions in COVID-19 that are associated with an increased susceptibility, disease severity and mortality from COVID-19.

Considerable neurological [61, 62], musculoskeletal [63, 64], mental or psychological or behaviour process [30, 34], reproductive system [65, 66] Eye diseases [67], and skin disease [68, 69] manifestations are observed during the infection and may have long-term complications. A higher preterm labour in pregnant women infected with COVID-19 [70] is also reported. However, we did not find any literature supporting major congenital anomalies due to COVID-19. Therefore, the prediction of the parent disease groups is nearly $90 \%$ accurate in our analysis.

\section{COVID-19 associated child diseases or conditions}

While we analysed for the important child diseases or conditions under each parent disease, we observed that, viral diseases constitute $75 \%$ of the diseases followed by bacterial infections under the parent infectious diseases. For neoplasm, liver, breast, gynaecologic, neurologic, and head and neck cancers are highly enriched. The key abnormal sign or symptoms are associated with blood followed by fever, pain, lung function and throat infection, fatigue, mental health, chest, and eye diseases. Under cardiovascular system disease, vascular diseases are the most frequent followed by myocardial disorders. The autoimmune diseases followed by immunodeficiency are the key diseases under the parent immune system disorder. Neurodegenerative disease, viral encephalitis, and other cerebral diseases are the top three conditions under nervous system disease category. The top three conditions under musculoskeletal system disease are bone inflammation disease, myopathy, and bone degenerative disease. Diabetes, lysosomal storage disease, metabolic syndrome $\mathrm{X}$, and cholesterol level are top candidates under metabolic disorder. For mental disorder, mood disorder is most frequent followed by cognitive disorder, autism, and sleep disorder. Under respiratory system disease, asthma, COPD, pulmonary sarcoidosis, pneumonia, and lung injury are the top 5 conditions. Inflammatory bowel diseases and kidney disease are respectively top conditions under gastrointestinal system and urinary system diseases, respectively. Therefore, this child disease analysis is also nearly $90 \%$ accurate if we compared with the symptoms and comorbid conditions of COVID-19 described in various literatures. The details of this analysis are given in Fig-3.

Apart from the above approach for child disease or symptoms analysis, we performed another enrichment analysis without considering the parent disease group (Fig-2B). In this analysis, we directly enriched the top child conditions based on their number of occurrences from the 404 classified parent - child - specific disease/symptom associations. In this analysis too, the viral infection is ranked one. The common comorbid conditions such as autoimmune disease (Rank-2) [50], vascular disease (Rank-4) [71], kidney disease (Rank-5) [56, 57], neurodegenerative disease (Rank-6) [72], bone inflammation disease (Rank-7) [73], myocardial disorder (Rank-7) [74], mood disorder (Rank-7) [34], breast cancer (Rank-10) [75], liver disease (Rank-10) [58], gynaecologic cancers (Rank-11) [76], asthma (Rank-12) [77], liver cancer (Rank-13) [78], musculoskeletal abnormality (Rank-14) [63], hematologic cancer (Rank-15) [79], retinal degeneration (Rank-15) [80], sepsis / septicaemia / septic shock (Rank-15) [60, 81], diabetes (Rank-16) [82], other cardiovascular diseases (Rank-17) [71, 74], viral encephalitis (Rank-17) [83], other cognitive disorder (Rank-18) [24], immunodeficiency (Rank-19) [84], brain disease (Rank-19) [85], COPD (Rank-19) [86], gastric / colon cancer (Rank-20) [87], autism (Rank-21) [88, 89], anemia (Rank21) [90], bone development and degenerative disease (Rank-20) [91], dyslipidaemia (Rank-22) [92, 
medRxiv preprint doi: https://doi.org/10.1101/2020.12.08.20245753; this version posted December 9, 2020. The copyright holder for this preprint (which was not certified by peer review) is the author/funder, who has granted medRxiv a license to display the preprint in It is made available under a cerpetuity. CC-BY-NC-ND 4.0 International license.

93], and ataxia (Rank-23) [94] etc. are among the top 25 child disease categories at a cut off score of 4 (Fig-2B). Inflammatory bowel disease which may not be a comorbid condition in COVID-19 [95] is found enriched (Rank-9). Importantly, nervous system neoplasms (Rank-16), myopathy (Rank-16), hematopoietic system disease (Rank-16), head and neck cancer (Rank-18), and pulmonary sarcoidosis (Rank-22) also came as top child diseases.
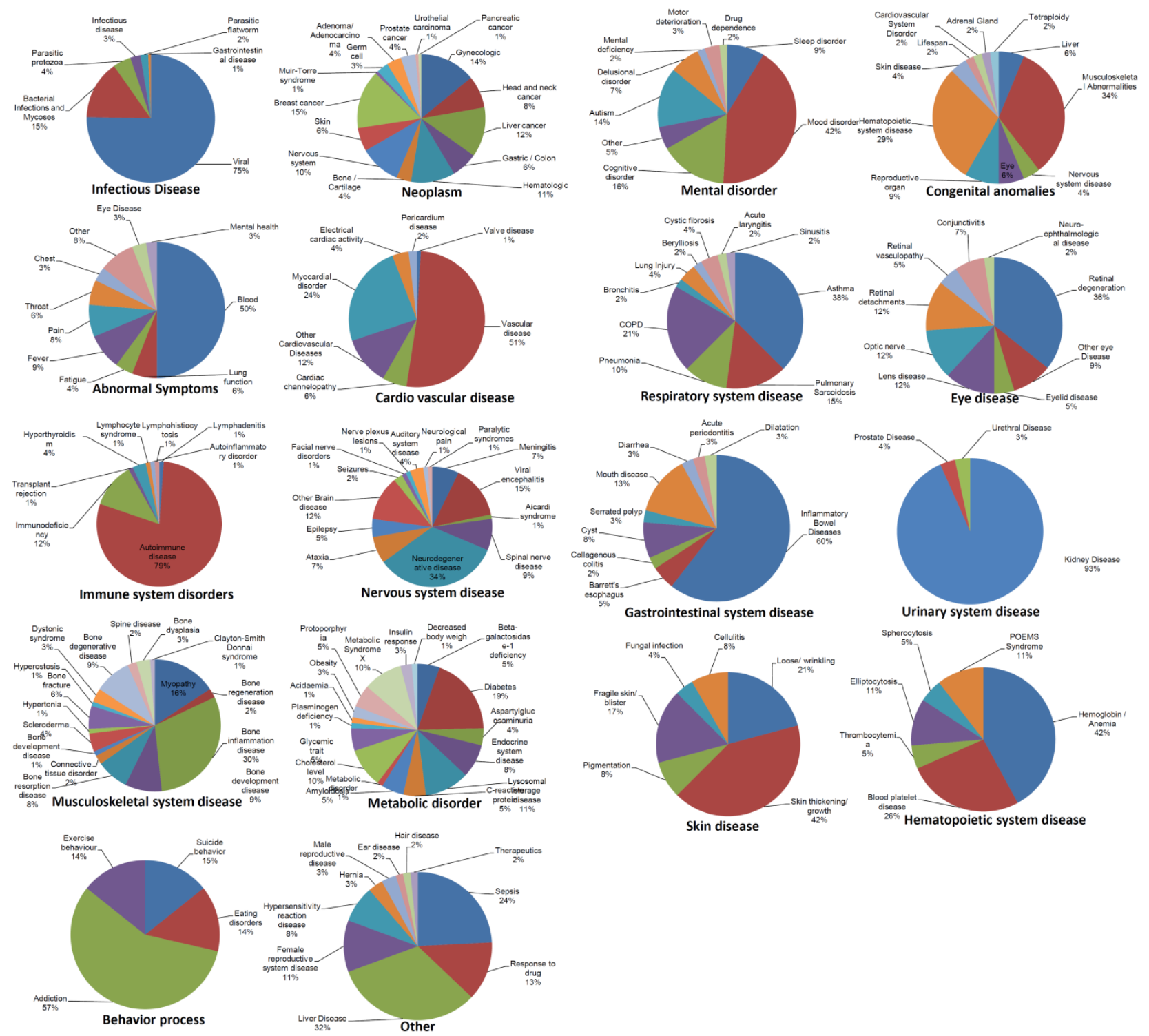

Fig-3: The proportion of child diseases under each parent disease

Apart from these diseases, general symptoms of COVID-19 such as, blood related abnormalities (Rank-3), fever / severe fever with thrombocytopenia syndrome (Rank-19) [5], pain (Rank-20) [18], lung/ pulmonary function (Rank-22) [96, 97], fatigue (Rank-24) [6], sleep disorder (Rank-24) [98], pneumonia [86], conjunctivitis (Rank-24) [99], skin diseases etc. are also enriched under top 25 child categories with occurrence cut off value of 4 . We also found many other reported COVID-19 associated diseases/symptoms enriched below the cut off 4 . For the details on the enriched child diseases/symptoms please see the Fig-2B.

Therefore, we achieved nearly $90 \%$ precision in identifying the diseases or symptoms associated with COVID-19 and hence the multi-omics based method we have developed and applied here is highly accurate and can be applied to other diseases too. 
medRxiv preprint doi: https://doi.org/10.1101/2020.12.08.20245753; this version posted December 9, 2020. The copyright holder for this preprint (which was not certified by peer review) is the author/funder, who has granted medRxiv a license to display the preprint in

It is made available under a CC-BY-NC-ND 4.0 International license .

\section{COVID-19 associated specific diseases and symptoms}

In this analysis, first we ranked the specific diseases and symptoms without considering the duration it takes to develop. Most commonly reported symptoms and comorbid conditions are found enriched in our analysis at a cut off specific disease occurrence score of 4 . Interestingly, some diseases/ symptoms reported in isolated COVID-19 cases are also found beyond the cut off 4 (Fig4).

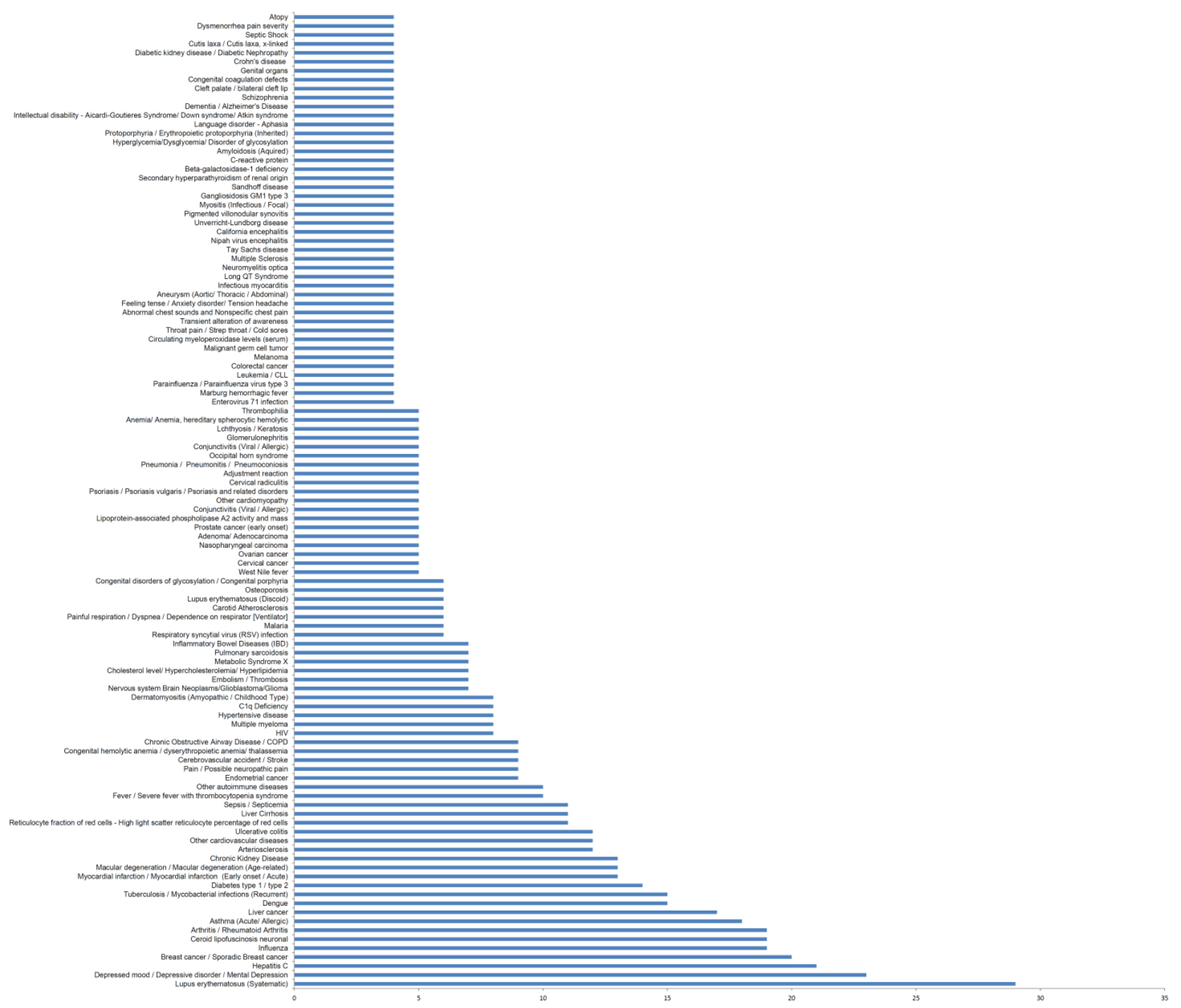

Fig-4: Top specific diseases without considering their duration to develop the clinical symptoms.

According to rank (with a cut off score 4), the enriched known or reported comorbid conditions or long-term complications are lupus erythematosus (Rank-1) [100], depressive disorder / mental depression (Rank-2) [30, 101], hepatitis C (Rank-3) [102], breast cancer (Rank-4) [75], arthritis (Rank-5) [103], asthma (Rank-6) [10, 77], liver cancer (Rank-6) [78], tuberculosis (Rank-7) [104, 105], diabetes (Rank-8) [82], myocardial infarction (Rank-9) [35, 106], macular degeneration (Rank-9) [80], chronic kidney disease (Rank-9) [56, 57], arteriosclerosis (Rank-10) [107], ulcerative colitis (Rank-10) [108], liver cirrhosis (Rank-11) [12, 109], sepsis / septicaemia /septic shock (Rank-11) [60, 81], other autoimmune diseases (Rank-12) [49, 50], cerebrovascular accident / stroke (Rank-13) [110], congenital anemia (Rank-13) [111], COPD (Rank-13) [86], multiple 
medRxiv preprint doi: https://doi.org/10.1101/2020.12.08.20245753; this version posted December 9, 2020. The copyright holder for this preprint (which was not certified by peer review) is the author/funder, who has granted medRxiv a license to display the preprint in

It is made available under a CC-BY-NC-ND 4.0 International license .

myeloma (Rank-14) [112], hypertensive disease (Rank-14) [9, 113], dyslipidemia (Rank-15) [93], metabolic syndrome $X$ (Rank-15) [51, 114], osteoporosis (Rank-16) [91], prostate cancer (Rank-17) [115], psoriasis (Rank-17) [116], leukemia (Rank-18) [117, 118], long QT syndrome (Rank-18) [119], dementia (Rank-18) [120], schizophrenia (Rank-18) [121], intellectual disability (Rank-18) [122, 123], diabetic kidney disease/ diabetic nephropathy (Rank-18) [124]etc.

In our analysis other clinical conditions such as ceroid lipofuscinosis neuronal (Rank-5), endometrial cancer (Rank-13), C1q deficiency (Rank-14), brain tumor (Rank-15), pulmonary sarcoidosis (Rank-15), congenital disorders of glycosylation (Rank-16), cervical and ovarian cancers (Rank-17), nasopharyngeal carcinoma (Rank-17), glomerulonephritis (Rank-17), thrombophilia (Rank-17), and melanoma (Rank-18) are also enriched. However, we could not get any report associating these conditions with COVID-19 (Fig-4). As in our analysis most of the diseases are found correlated with COVID-19, we presume that these conditions could also be either comorbid or long-term consequences of COVID-19.

Further, in this analysis, we also found some diseases that are not so far reported to be associated with the increased risk or severity of COVID-19 such as HIV (Rank-14) [125], IBD (Rank-15) [95], and neuromyelitis optica (Rank-18) [126]. Interestingly, we also found atopy at Rank-18 which is found to have a protective role from severe complications of COVID-19 [127, 128].

In this analysis, we also found several common symptoms (mild, severe, and long-term complications) of COVID-19 are enriched at a cut off value 4. These include influenza (Rank-5) [129], dengue (Rank-7) [130], fever / severe fever with thrombocytopenia syndrome (Rank-12) [5], pain (Rank-13) [18], dermatomyositis (Rank-14) [131], embolism / thrombosis (Rank-15) [132], dyspnea / dependence on respirator (ventilator) (Rank-16) [5], conjunctivitis (Rank-17) [99], pneumonia / pneumonitis (Rank-17) [86], lchthyosis / keratosis (Rank-17) [133], throat pain / strep throat / cold sores (Rank-18) [134], fatigue/ transient alteration of awareness (Rank-18) [5], abnormal chest sounds and nonspecific chest pain (Rank-18) [134], anxiety disorder (Rank-18) [135], infectious myocarditis (Rank-18) [136, 137], aneurysm (Rank-18) [138], and myositis (Rank-18) [139], (Fig-4). However, we could not find any report of COVID-19 association with cervical radiculitis (Rank-17), adjustment reaction (Rank-17), and dysmenorrhea pain (Rank-18).

Similar to the previous analysis, in this ranking we also found many diseases/symptoms reportedly associated with COVID-19 below the cut off 4. For example lactate dehydrogenase level (Rank 21) and D-dimer level (Rank 21) [16] etc. For the full list of the specific diseases/symptoms please see the (Fig-4).

\section{COVID-19 associated specific diseases, symptoms, and complications based on their time to develop}

For better understanding of the COVID-19 associated specific clinical conditions based on our multi-omics profiles, we classified the 403 specific disease or symptoms based on the time or duration it takes to develop and if genetics is also involved. We grouped the diseases under six categories: short, short-mid, mid - long, short - mid - long, short - mid - long (genetic), mid - long (genetic), and congenital/ genetic. 
medRxiv preprint doi: https://doi.org/10.1101/2020.12.08.20245753; this version posted December 9, 2020. The copyright holder for this preprint (which was not certified by peer review) is the author/funder, who has granted medRxiv a license to display the preprint in

It is made available under a CC-BY-NC-ND 4.0 International license.

\section{Short-term diseases or signs and symptoms}

Under this group, we classified the diseases/ signs/ symptoms under two groups: infectious and non-infectious or non-communicable diseases (NCDs). We found 35 infectious diseases are enriched and the top five diseases at a cut off count of occurrence of 4 are influenza (Rank-1), dengue (Rank-2), respiratory syncytial virus (RSV) infection (Rank-3), malaria (Rank-3), West Nile fever (Rank-4), marburg hemorrhagic fever (Rank-5) etc. (Fig-5A). For the non-infectious disease/ NCDs or signs and symptoms group, we found 54 different short-term conditions. Among these, high light scatter reticulocyte percentage of red cells (Rank-1), sepsis or septicaemia (Rank-1), fever / severe fever with thrombocytopenia syndrome (Rank-2), pain (Rank-3), painful respiration or dyspnea or dependence on respirator (ventilator) (Rank-4), lipoprotein-associated phospholipase A2 activity and mass (Rank-5), conjunctivitis (Rank-5), pneumonia (Rank-5), thrombophilia (Rank5), serum myeloperoxidase level (Rank-6), throat pain or strep throat (Rank-6), fatigue/ transient alteration of awareness (Rank-6), abnormal chest sounds and pain (Rank-6), anxiety and headache (Rank-6), viral encephalitis (Rank-6), C-reactive protein level (Rank-6), and septic shock (Rank-6) are the top conditions with the cut off occurrence score of 4 . The details of these diseases or symptoms are presented in Fig-5A.
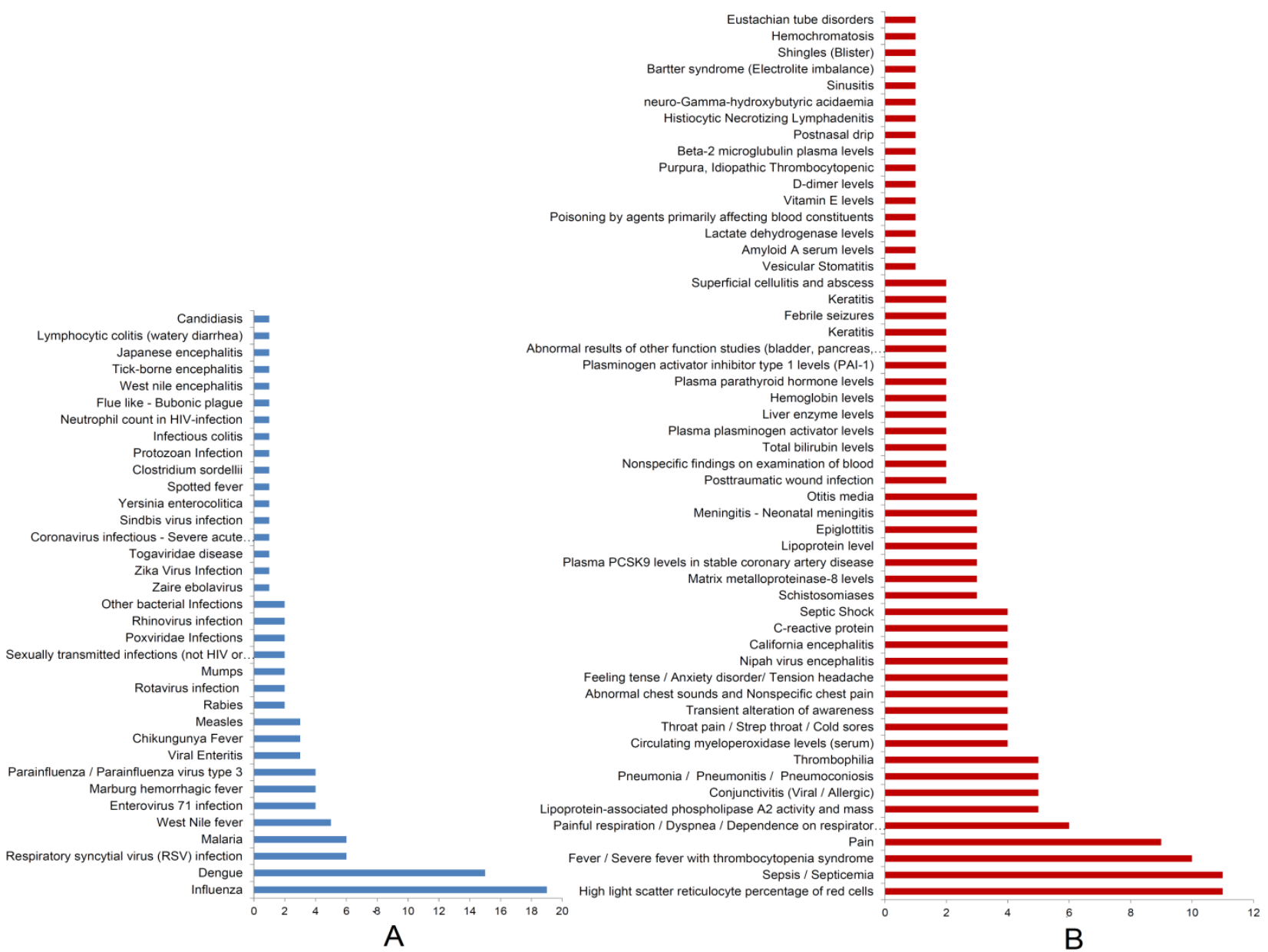

Fig-5: A) Short-term infectious diseases, B) Short-term NCDs/ signs/ symptoms

According to WHO, most common symptoms in COVID-19 are fever, dry cough and, tiredness. The less common symptoms include ache and pain, sore throat, diarrhoea, conjunctivitis, headache, loss of taste or smell, skin rash, and discolouration of toes or fingers. The serious symptoms that require medical interventions are breathing difficulty or shortness of breath, chest pain or pressure, 
medRxiv preprint doi: https://doi.org/10.1101/2020.12.08.20245753; this version posted December 9, 2020. The copyright holder for this preprint (which was not certified by peer review) is the author/funder, who has granted medRxiv a license to display the preprint in

It is made available under a CC-BY-NC-ND 4.0 International license .

and loss of speech or movement [140]. COVID-19 and influenza shares many common symptoms however, there are many differences too [141]. In our short-term infectious disease analysis, we observed that, influenza is the top candidate followed by dengue, respiratory syncytial virus (RSV) infection, and malaria (Fig-5A). Literature also suggests that COVID-19 shares symptoms of dengue [130] and differential diagnosis includes all kinds of respiratory viral infections including respiratory syncytial virus (RSV) [142]. Similarly, malaria also shares many important symptoms of COVID-19 [143]. Therefore, the viral infections enriched in our analysis are highly accurate and all the viral diseases flagged in our analysis need to be considered with differential diagnosis for COVID-19.

While we considered the short-term specific non- infectious diseases/NCDs/ signs / symptoms, we found that most of the COVID-19 symptoms as described by WHO [140] such as fever / severe fever with thrombocytopenia syndrome (Rank-2) [144], pain (Rank-3) [145], painful respiration / dyspnea / dependence on respirator [Ventilator] (Rank-4) [5], conjunctivitis (Rank-5) [99], pneumonia (Rank-5) [86], headache (Rank-6) [145, 146], transient alteration of awareness (tiredness/ fatigue) (Rank-6) [5], strep throat/ sore throat (Rank-6) [134], abnormal chest sounds and nonspecific chest pain (Rank-6) [134] are found in our top ranked symptoms (Fig-5A). However, dry cough, loss of taste or smell, and loss of speech or movement are not enriched as short-term symptoms. Interestingly, high light scatter reticulocyte percentage of red cells is found as the top candidate (Rank-1) sign in our analysis. Recently, high reticulocyte is reported to be significantly higher in critical patients and may be a prognostic predictor for poor outcomes [147] . Similarly, sepsis or septicemia is also enriched at Rank-1 in our analysis and sepsis is found to worsen the condition of critically ill COVID-19 patients [60].

The cardiovascular diseases biomarker lipoprotein-associated phospholipase A2 (PLA2G7) is highly upregulated in severe COVID-19 pneumonia [148]. In our result, we found the lipoproteinassociated phospholipase A2 activity is ranked at 5. Thrombophilia, which also came at Rank-5, is highly prevalent in COVID-19 patients, however, is not associated with disease severity [149]. Myeloperoxidase could be a potential biomarker for detection of SARS-CoV-2 infection [150]. The serum myeloperoxidase level is found enriched at Rank-6 along with viral encephalitis, C-reactive protein, and septic shock (Fig-5A). Encephalitis is frequent in older patients having age group $>50$ and mostly develops while under treatment in ICU [83], level of C-reactive protein is positively associated with lung lesions and disease severity in COVID-19 [151], and 70\% of COVID-19 nonsurvivors develop septic shock [152]. Schistosomiases, matrix metalloproteinase level, plasma PCSK9 levels, lipoprotein level, epiglottitis, meningitis, and otitis media are found at Rank-7 (with the cut off occurrence score of 3) in our analysis. An early up-regulation of circulating MMP-9 is associated with respiratory failure in COVID-19 [153], and lipoprotein level is associated with severity of COVID-19 [93], while in September 2020 acute epiglottitis [154] and meningitis as initial symptoms of COVID-19 [155] are found in two separate COVID-19 patients. Similarly, otitis media is also observed in isolated cases [156]. Several conditions came at Rank-8 with a cut off occurrence score of 2. Among them, higher bilirubin level is observed in severe COVID-19 cases [157], plasminogen activator inhibitor type 1 (PAI-1) is upregulated and extremely high levels of plasminogen activator (tPA) enhance spontaneous fibrinolysis and mortality [158], and lower haemoglobin level is observed in severe COVID-19 cases [159]. Deregulation of parathyroid hormone level [160, 161], elevated liver enzyme levels [162], keratitis [163], febrile seizures [164, 165], cellulitis and sinusitis [166] are reported in isolated COVID-19 cases. Higher level of blood 
medRxiv preprint doi: https://doi.org/10.1101/2020.12.08.20245753; this version posted December 9, 2020. The copyright holder for this preprint (which was not certified by peer review) is the author/funder, who has granted medRxiv a license to display the preprint in It is made available under a CC-BY-NC-ND 4.0 International license .

lactate dehydrogenase and D-dimer (Rank-9, score-1) is associated with disease severity in COVID19 [16] (Fig-5A).

Therefore, $\sim 90 \%$ of our predicted short-term diseases/symptoms/conditions associated with COVID-19 are correct at an occurrence cut off of 4 and several conditions associated with COVID19 are also found enriched beyond the occurrence cut off of 4 indicating the high accuracy of the method we have developed. Further, majority of these identified diseases/symptoms/conditions are associated with COVID-19 severity and disease outcomes. Therefore, we predict that the signs and symptoms that we have identified, but not discussed or so far not reported in the literature may also be associated with COVID-19.

\section{Short - Mid and Short -Mid -Long term diseases or conditions}

Under short to mid conditions, the top three conditions are hyperglycemia or dysglycemia (Rank1), abnormal erythrocyte morphology (Rank-1), and chronic ulcer (Rank-1) (Fig-6A). COVID-19 is reported to aggravate dysglycemia and in diabetic patients, it leads to hyperglycemia and poor patient outcomes [167]. COVID-19 patients with sepsis shows adverse effects on red blood cell morphology [168], and re-bleeding from peptic ulcer is common in COVID-19 patients [169].

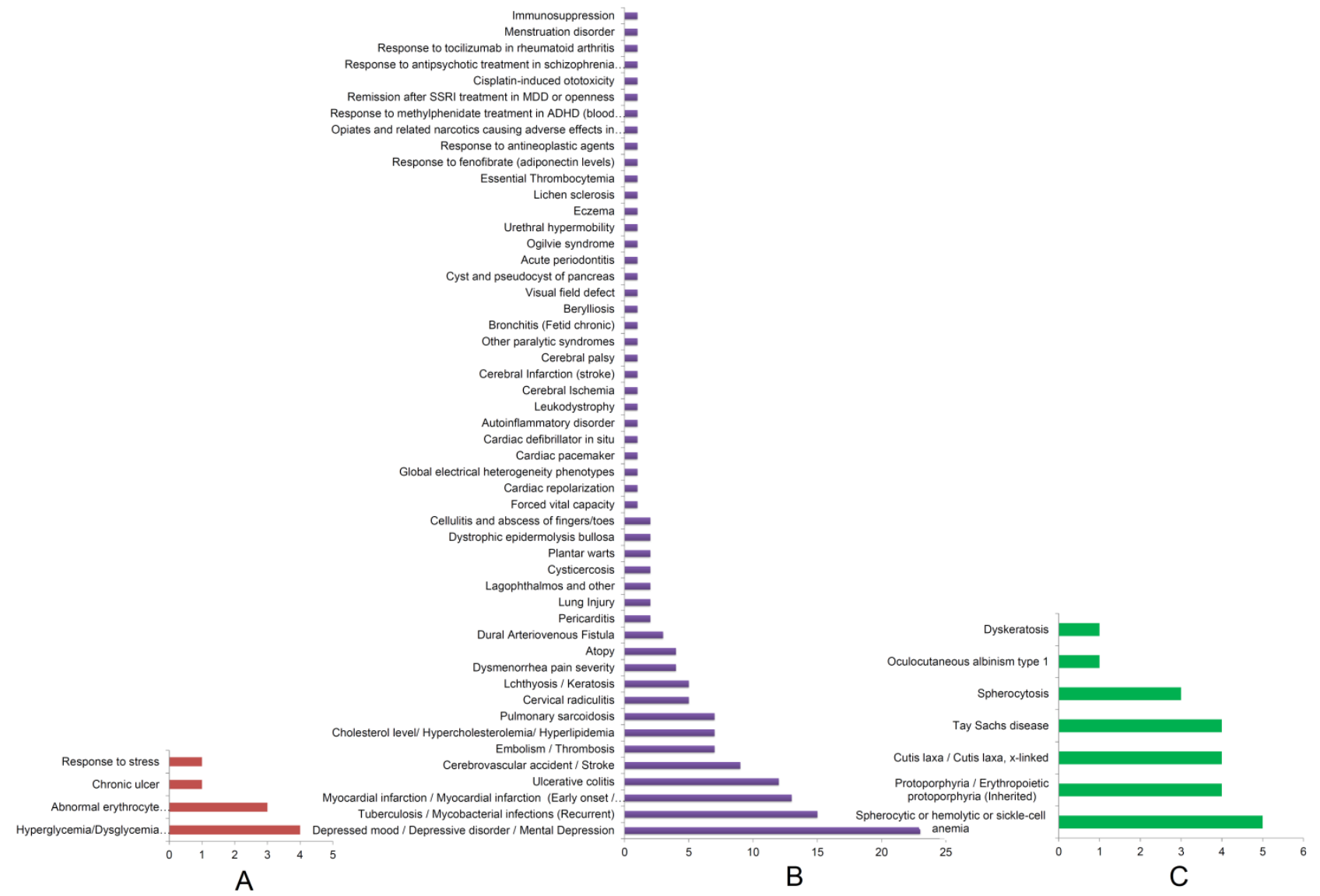

Fig-6: A) Short to mid specific NCDs / conditions. B) Short to mid to long specific NCDs / conditions. C) Short to mid to long (genetic) specific NCDs / conditions.

Under Short to Mid to Long conditions, the top five conditions found to be enriched are depressive disorders or depressed mood or mental depression at first rank (Rank-1) followed by recurrent mycobacterial infections (Rank-2), myocardial infarction (Rank-3), ulcerative colitis (Rank-4), and cerebrovascular accident or stroke (Rank-5). Embolism or thrombosis, cholesterol 
medRxiv preprint doi: https://doi.org/10.1101/2020.12.08.20245753; this version posted December 9, 2020. The copyright holder for this preprint (which was not certified by peer review) is the author/funder, who has granted medRxiv a license to display the preprint in It is made available under a CC-BY-NC-ND 4.0 International license .

level, and pulmonary sarcoidosis came at Rank-6. Cervical radiculitis and lchthyosis or keratosis are found to enrich at Rank -7. Dysmenorrhea pain and atopy are ranked at Rank-8 with an occurrence cut off of 4 followed by dural arteriovenous fistula (Rank-9) with an occurrence cut off of 3. Pericarditis, lung injury, lagophthalmos, cysticercosis, plantar warts, dystrophic epidermolysis bullosa, and cellulitis and abscess of fingers/toes are enriched at Rank-10 with a cut off occurrence score of 2 (Fig-6B).

Current evidence suggests that COVID-19 shows various mental health problems including depression and mood and anxiety disorders [30, 101]. Nearly 28\% COVID-19 patients are found to develop depressive mood disorders during their treatment [170] and acute COVID-19 patients may develop delirium in a significant proportion [171]. A recent report suggests that, a considerable percentage of COVID-19 patients develop mental disorders post recovery from the disease (14-90 days) and the patients having previous history of psychiatric disorders have higher incidence of COVID-19 [34]. Some reports suggest a higher mortality rate (11.6\% to 14.3\%) in patients with tuberculosis and COVID-19 co-infection [104, 105]. Myocardial infarction that came at Rank-3 is reported to be one of the most frequent cardiovascular syndromes in COVID-19 [35, 106] and in a meta-analysis ulcerative colitis (Rank-4) is found in 41.6\% COVID-19 patients [108] and represents more severe symptoms than the patients with Crohn's disease [172]. In a single centre study, although stroke (Rank-5) is observed in 4.6\% [173] and in a meta-analysis 1.1\% COVID-19 cases; COVID-19 patients having stroke show severe symptoms, poorer prognosis, and $46.7 \%$ mortality rate [110]. Pulmonary embolism (Rank-6) and deep vein thrombosis are reported in $20 \%-40 \%$ and $0 \%$ to $69 \%$ cases in COVID-19, respectively [132]. A sharp decrease in total cholesterol level (Rank-6) and low-density lipoprotein is observed in COVID-19 patients [92] and hypolipidemia correlates with COVID-19 severity [93]. Skin disease Keratosis that came at Rank-7 with an occurrence cut off of 5 is observed as a symptom in COVID-19 [133] and a prehistory of actinic keratosis exhibit 10.8\% COVID-19 cases [116]. Acute pericarditis (Rank-10) is reported as a primary symptom in COVID-19 in some cases [174] and lung injury (Rank-10) during COVID-19 and subsequent pulmonary fibrosis in COVID-19 survivors are a frequent finding [175]. Interestingly, atopy that came at Rank 8 with cumulative score of 4 is reported to show positive effect in COVID-19. SARS-CoV-2 infected patients having prehistory of atopy require less hospitalization and showed decreased mortality [127] (Fig-6B). Similarly, menstruation has some protective effect from COVID-19 [176]. We could not find any literature showing correlation of COVID-19 with pulmonary sarcoidosis (Rank-6), cervical radiculitis (Rank-7), and dysmenorrhea pain severity (Rank-8). As in this analysis, we also found $>90 \%$ precision at a cut off count of occurrence of 4 , our other identified specific disease or symptoms could also be correlated with COVID-19 either in the form of a disease or comorbidity or long-term effect of COVID-19.

Since we have used OMIM Expanded and Rare Diseases databases in our Enricher-based [42] prediction, we got several genetic diseases as top candidates associated with COVID-19. These diseases are as follows: hereditary spherocytic/ haemolytic/ sickle cell anemia is the top disease (Rank-1) followed by erythropoietic protoporphyria (Rank-2), Cutis laxa, x-linked (Rank-2), Tay Sachs disease (Rank-2), spherocytosis (Rank-3), and dyskeratosis (Rank-4) (Fig-6C). COVID-19 severity is associated with anemia [90] and patients with sickle cell anemia are at higher risk of developing severe COVID-19 [111]. However, we don't see any report on our other identified genetic diseases and their correlation with COVID-19. Nevertheless, based on the high confidence 
medRxiv preprint doi: https://doi.org/10.1101/2020.12.08.20245753; this version posted December 9, 2020. The copyright holder for this preprint (which was not certified by peer review) is the author/funder, who has granted medRxiv a license to display the preprint in

It is made available under a CC-BY-NC-ND 4.0 International license .

of our analysis, we presume that the identified genetic conditions need careful observation on their genetic disease - COVID-19 interactions and outcomes in the long term.

\section{Mid - long term diseases or conditions}

While we classified the mid - long term diseases or conditions into infectious, non-infectious, and genetics disease, four infectious diseases are enriched. These diseases are hepatitis C (Rank 1) followed by HIV (Rank 2), hepatitis B (Rank 3), and melioidosis (Rank 4) (Fig-7A). Hepatitis is recently found to be a comorbid condition in COVID-19. In a systematic review it is reported that $14.1 \%$ and $21.4 \%$ of COVID-19 patients with hepatitis $\mathrm{B}$ and hepatitis $\mathrm{C}$ require ICU admission and hepatitis $\mathrm{C}$ confers $13 \%$ increased risk of fatality in COVID-19 patients [102]. However, people living with HIV (PLHIV) do not show poorer outcomes from COVID-19 [125]. We did not get any report on correlation between melioidosis and COVID-19.

The top 17 non-infectious diseases or NCD conditions enriched at a cut off occurrence score of 4 as per their rank are systematic lupus erythematosus (Rank-1), breast cancer (Rank-2), arthritis or rheumatoid arthritis (Rank-3), asthma (Rank-4), liver cancer (Rank-5), and diabetes (Rank-6). At Rank-7 macular degeneration, and chronic kidney disease are enriched with a cut off score of 13. Arteriosclerosis, liver cirrhosis, and other autoimmune diseases came at Rank-8, -9, and -10, respectively. Endometrial cancer, pain/ neuropathic pain, and COPD are enriched at Rank-11. At Rank-12, three diseases are enriched with a cut off score of 8 . These diseases are multiple myeloma, hypertension/ hypertensive disease, and dermatomyositis. Glioma, metabolic syndrome X, and inflammatory bowel disease are Ranked at 13. At Rank-14 carotid atherosclerosis, osteoporosis, and lupus erythematosus (discoid) are found. Nine diseases are ranked at 15 . They are cervical cancer, ovarian cancer, nasopharyngeal carcinoma, prostate cancer, other cardiomyopathy, psoriasis, adjustment reaction, and glomerulonephritis. At Rank-16, nineteen diseases are enriched with a cut off score of 4. These diseases are leukemia, colorectal cancer, melanoma, malignant germ cell tumor, aneurysm, infectious myocarditis, neuromyelitis optica, multiple sclerosis, UnverrichtLundborg disease, pigmented villonodular synovitis, myositis, secondary hyperparathyroidism of renal origin, acquired amyloidosis, aphasia, dementia or Alzheimer's disease, schizophrenia, Crohn's disease, and diabetic kidney disease / diabetic nephropathy. Several other conditions are also enriched and the full list is given in Fig-7B.

Literature suggests that lupus (Rank-1) patients are more vulnerable to COVID-19 [100] and breast cancer (Rank-2) patients infected with COVID-19 show 13\% mortality rate [75]. Arthritis that came at Rank-3 is reported to increase risk and severity of COVID-19 [103]. Although asthma came at Rank-4 and a comorbid condition, it may not increase the mortality rate [10,77]. Hepatic injury is observed in 10-40\% of patients with COVID-19 and therefore, in liver cancer (Rank-5) patients, COVID-19 aggravates the disease severity [78]. Diabetes that came at Rank-6 is having a bidirectional association with COVID-19. Diabetes increases the risk of severe COVID-19 or COVID-q9 associated mortality and patients with COVID-19 show early onset diabetes and severe metabolic complications associated with the disease [33, 82, 113]. Patients having a history of macular degeneration and or chronic kidney disease (Rank-7) are at increased risk of COVID-19 associated morbidity and mortality [80, 177, 178]. Reports suggest that arteriosclerosis or coronary artery calcification at Rank-8 is associated with worse prognosis [107] and liver cirrhosis (Rank-9) is associated with increased deaths in COVID-19 [12, 109]. Similarly, other autoimmune disease 
medRxiv preprint doi: https://doi.org/10.1101/2020.12.08.20245753; this version posted December 9, 2020. The copyright holder for this preprint (which was not certified by peer review) is the author/funder, who has granted medRxiv a license to display the preprint in

It is made available under a CC-BY-NC-ND 4.0 International license .

(Rank-10) is also associated with increased risk of COVID-19 [50]. Neuropathic pain and COPD at Rank-11 are also found to associate with COVID-19. Reports suggest that nearly $2.3 \%$ of COVID19 patients display neuropathic pain $[179,180]$ and COPD patients are at high risk of developing severe pneumonia and poor outcomes if infected with SARS-CoV-2 [86].

Multiple myeloma and hypertension enriched at Rank-12 are also comorbid conditions. Multiple myeloma is associated with severe COVID-19 [112] and hypertension is found in 46\% cases and is associated with severity and mortality of COVID 19 [9, 48, 113]. Similarly, other metabolic syndromes (Rank-13) are also associated with severity and death of COVID 19 [51, 114]. Individuals suffering from osteoporosis (Rank-14) [91], cardiomyopathy (Rank-15) [15], and psoriasis (Rank-15) are at high risk of developing severe COVID-19 [91].

With a cut off occurrence score of 4 or (Rank-16), we found several conditions that are associated with COVID-19. Subarachnoid hemorrhage (SAH) is observed in COVID-9 patients and instability of aortic aneurysm is associated with SAH [138]. Myocarditis is one of the direct consequences (7\% - 23\%) of SARS-CoV-2 infection and is associated with higher degree of morbidity and mortality from COVID-19 [136, 137]. Neurological changes caused by COVID-19 show similarities with multiple sclerosis [181] and myositis is a manifestation of SARS-CoV-2 infection [139]. Amyloid microclots are found in the native plasma of COVID-19 [182] and in diabetic patients, serum amyloid A (SAA) level may be associated with the severity of COVID-19 [183]. Aphasia is found in COVID-19 patients who have developed encephalopathy or ischemic stroke $[184,185]$. Recent literature suggests that people suffering from dementia or Alzheimer's disease are at high risk of being infected and developing severe symptoms of COVID-19 [186, 187]. Similar to dementia, schizophrenia patients are also at higher risk of SARS-CoV-2 infection and poorer outcomes [121]. Although, patients with Crohn's disease exhibits less severe symptoms as compared to ulcerative colitis [108, 172], patients with diabetic nephropathy shows $>2$ fold COVID-19 associated pneumonia and higher mortality as compared to other chronic kidney disease [124]. As mentioned earlier, two conditions IBD (Rank-13) and neuromyelitis optica (Rank-16) may not be associated with COVID-19 associated risk or severity [95, 126]. On the other hand, literature suggests that COVID-19 may trigger the development of dermatomyositis (Rank-12) [131] and Glioma (Rank13) [188]. Similar to other analysis, we also found several COVID-19 associated conditions below the occurrence cut off value of 4. Interestingly, in this group at Rank-19, we found specific psychiatric disorders such as suicide tendency addiction. Recent report suggests that substance use disorders (SUD) or drug addicted people are at higher risk of being infected and develop severe COVID-19 [189]. Similarly, COVID-19 positive patient without a pre-history of any psychiatric condition is reported to show confusion, psychotic symptoms, and suicide attempt [190]. Therefore, in this analysis also we achieved $\sim 90 \%$ accuracy in identifying comorbid or long-term consequences of COVID-19.

Importantly, we observed a lot of cancers enriched in our analysis such as breast cancer (Rank-2), liver cancer (Rank-5), endometrial cancer (Rank-11), cervical cancer, ovarian cancer, nasopharyngeal carcinoma, prostate cancer (Rank-15), leukemia, colorectal cancer, melanoma, malignant germ cell tumor (Rank-16), chondroma (Rank-17), sarcoma, lymphoma, larynx cancer (Rank-18), esophagal cancer, pharynx cancer, squamous cell carcinoma of mouth (Rank-19) among others (Fig-7B). Considering our analysis that is showing high confidence in identifying the COVID-19 related conditions and complications, coupled with the facts that (i) some of these cancers such as breast cancer [75], liver cancer [78], gynaecologic cancers [76], hematologic [79], colon cancer [87], prostate cancer [115] are already reported as comorbid conditions, (ii) glioma 
medRxiv preprint doi: https://doi.org/10.1101/2020.12.08.20245753; this version posted December 9, 2020. The copyright holder for this preprint (which was not certified by peer review) is the author/funder, who has granted medRxiv a license to display the preprint in perpetuity.

perpetuity.
CC-BY-NC-ND 4.0 International license .

may be developed due to COVID-19 [188], and the fact of viral carcinogenesis process[191, 192]; we hypothesize that the cancers we have identified in our analysis could be the long-term consequence of COVID-19.

The genetic diseases that are identified for mid to long term based analysis are ceroid lipofuscinosis neuronal (Rank-1), C1q deficiency (Rank-2), long QT syndrome (Rank-3) Papillon Lefevre syndrome (Rank-3), Polyglandular syndrome (Rank-5), familial idiopathic basal ganglia calcification (Rank-5), and spinocerebellar ataxia (Rank-5) (Fig-7C). We could not find any literature correlating COVID-19 with these genetic conditions. Since our analysis is giving high accuracy in identifying COVID-19 associated conditions, a careful and long observation is required to understand if there is any association of SARS-CoV-2 infection with these genetic conditions.

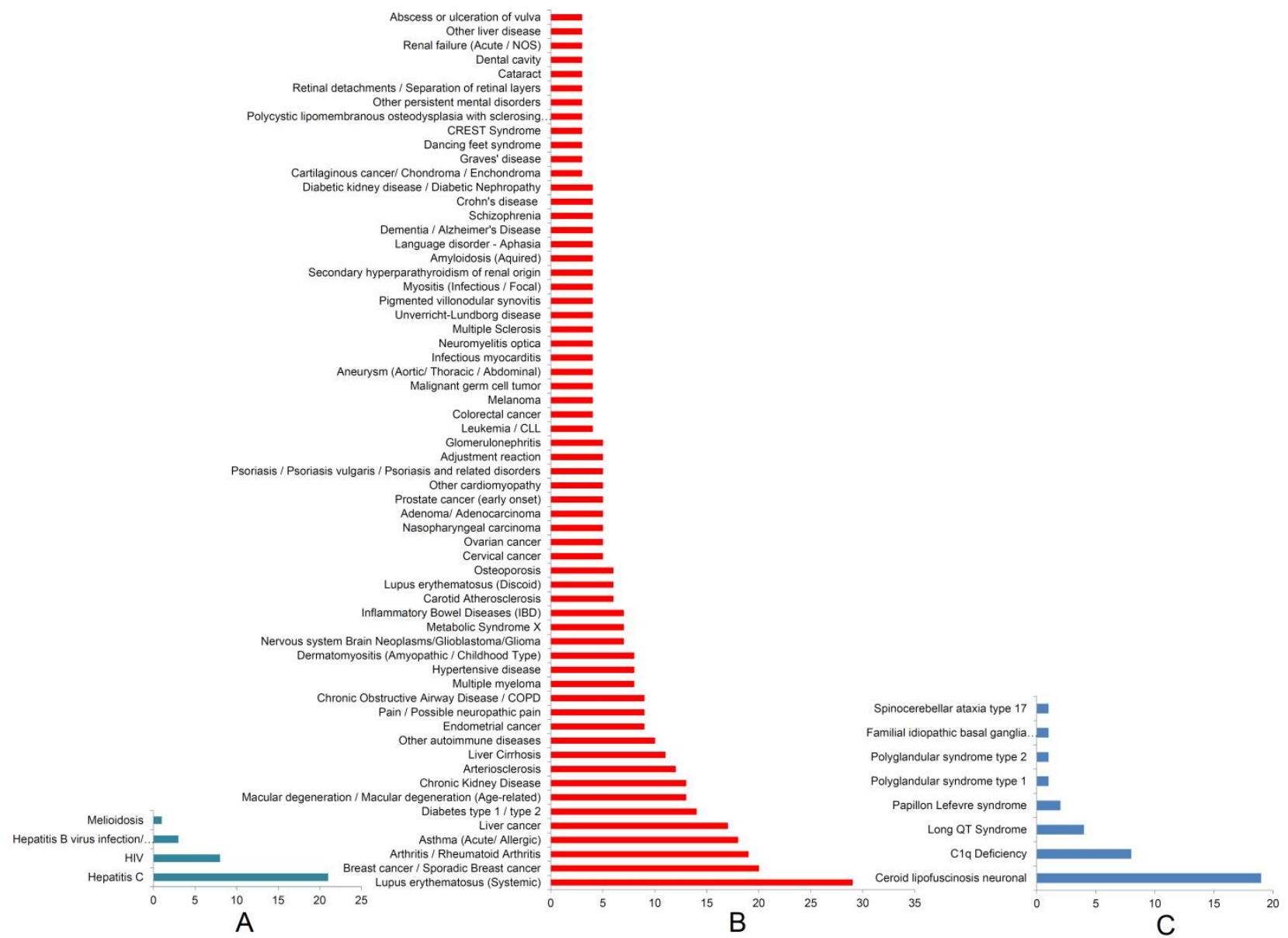

Fig-7: A) Mid to long specific infectious diseases. B) Mid to long specific NCDs / conditions. C) Mid to long (genetic) specific NCDs / conditions.

\section{Congenital and genetic diseases}

Interestingly in our analysis, we found 57 congenital or genetic diseases that could be related to COVID-19. The top three diseases are congenital hemolytic anemia (Rank-1), congenital disorders of glycosylation (Rank-2), and occipital horn syndrome (Rank-3). At Rank-4 with an occurrence cut off score of 4, we found seven diseases and they are gangliosidosis GM1 type 3, Sandhoff disease, beta-galactosidase-1 deficiency, syndrome associated intellectual disability, cleft palate, congenital coagulation defects, and genital organ defects. With an occurrence cut off score of 3, ceroid storage disease and aspartylglucosaminuria are enriched at Rank-5. Adrenoleukodystrophy, paget disease of bone, asperger syndrome, autism spectrum disorder, microcephaly, arthrogryposis, congenital limbs 
medRxiv preprint doi: https://doi.org/10.1101/2020.12.08.20245753; this version posted December 9, 2020. The copyright holder for this preprint (which was not certified by peer review) is the author/funder, who has granted medRxiv a license to display the preprint in It is made available under a CC-BY-NC-ND 4.0 International license .

defect, cystic fibrosis, rhizomelic chondrodysplasia punctate, fetal hemoglobin quantitative trait locus, and familial erythrocytosis are found at Rank-6 with an occurrence cut off score of 2 . The complete list of this group of diseases is given in Fig-8).

Among these identified diseases, some congenital diseases have been reported to show positive or negative correlation with COVID-19. However, majority of the congenital diseases identified here have no information so far on their association with COVID-19. Patients with hemolytic anemia (Rank-1), specifically sickle cell anemia are at higher risk of developing severe COVID-19 [111]. Down syndrome (Rank-4) that represents intellectual disability exhibits 4-fold increased risk of severity and 10-fold increased risk of mortality from COVID-19 [193] and autism spectrum disorder (Rank-6) may also be a risk factor [88, 89]. On the other hand, congenital coagulation defects (Rank-4) or congenital bleeding disorders are associated with more favourable outcomes of COVID-19 [194] and fetal hemoglobin (Rank-6) may play a protective role against COVID-19 as the neonates, infants, and children show low prevalence of SARS-CoV-2 infection [195, 196]. Cystic fibrosis (Rank-6) patients may be at risk but are probably not vulnerable to COVID-19 due to their current treatment of cystic fibrosis [197, 198] and according to Paget's Association, Paget's disease (Rank-6) is not a risk factor for COVID-19 [199]. As our analysis is providing some important congenital disease and COVID-19 associations, the effect of COVID-19 on our other identified congenital conditions require careful and long-term investigation to find if there is any correlation.

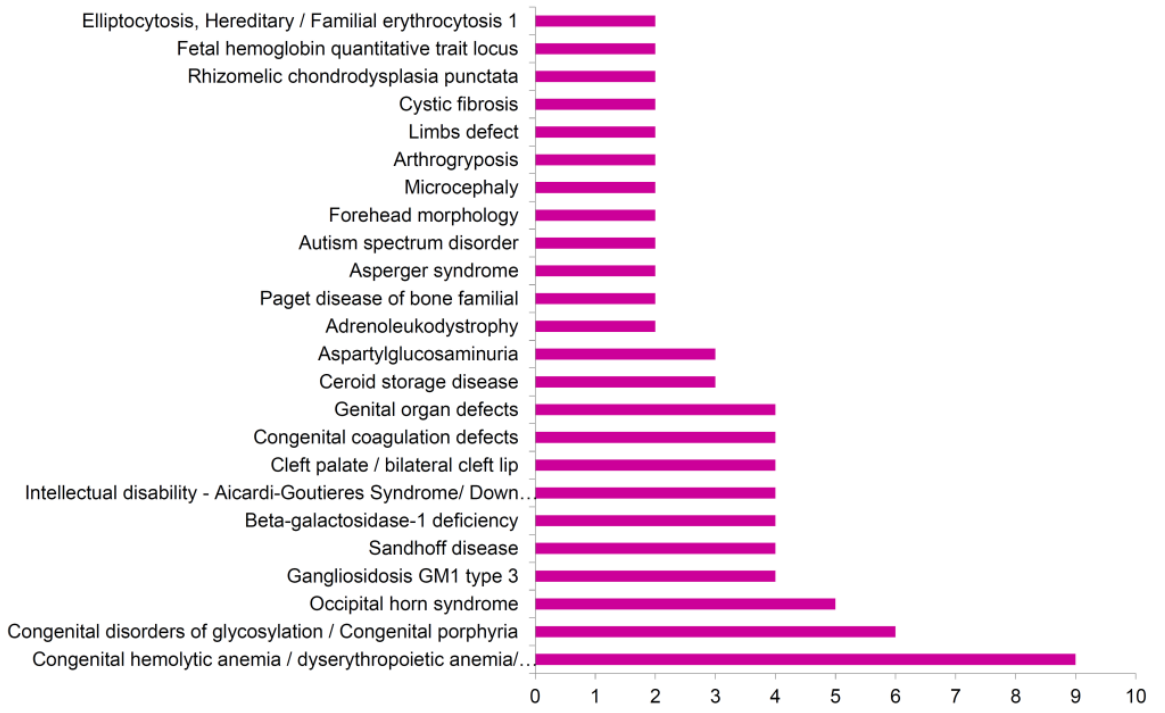

Fig-8: Congenital and genetic diseases associated with COVID-19.

\section{Long-term consequences of COVID-19}

WHO predicted that COVID-19 could cause long-term health complications such as cardiac muscle damage and heart failure, damage of lung tissue and lung failure, anosmia, pulmonary embolism, heart attack, stroke, cognitive impairment, anxiety, depression, post-traumatic stress disorder, sleep disorder, pain in muscles and joint, fatigue [31]. A recent report suggest that nearly $70 \%$ young and low-risk COVID-19 survivors develop one or more organs impairment within four months after initial symptoms of SARS-CoV-2 infection. Impairment of heart is observed in $32 \%$ cases, lungs (33\%), kidneys (12\%), liver (10\%), pancreas (17\%), and spleen $(6 \%)$. Further, single organ damage is observed in $66 \%$ cases while multi-organ injury is found in $25 \%$ subjects [32]. It is also reported recently that one in five COVID-19 survivors develops mental illness for the first time such as 
medRxiv preprint doi: https://doi.org/10.1101/2020.12.08.20245753; this version posted December 9, 2020. The copyright holder for this preprint (which was not certified by peer review) is the author/funder, who has granted medRxiv a license to display the preprint in It is made available under a CC-BY-NC-ND 4.0 International license .

anxiety, depression, and insomnia within 90 days from the first COVID-19 symptoms shown and COVID-19 patients having pre-existing psychiatric disorder are at risk of COVID-19 severity [34]. The individuals recovering from COVID-19 are also developing substance use disorder [22], confusion, psychotic symptoms, and suicide tendency [30, 190]. Apart from these, COVID-19 is found to trigger arthritis [200], dermatomyositis [131], glioma [188], and early onset of diabetes and severe metabolic complications [33]. Considering the facts that (i) all these NCDs and mental health conditions are found enriched at top ranks in our analysis along with several conditions, (ii) high confidence of our analysis ( $90 \%$ ), (iii) most of our identified conditions are associated with severity of COVID-19, (iv) the bidirectional relationship between diabetes and COVID-19 [33], psychiatric disorder and COVID-19 [34], COVID-19 and cardiovascular system diseases [35], (v) presence of SARS-CoV-2 viral RNA in patients body for long time after recovery [20], and (vi) our "genetic remittance" assumption [43]; we hypothesize that in long-term, COVID survivors may develop various conditions we have identified in this analysis. However, as COVID-19 is a new disease, long-term observational studies are required on COVID-19 survivors to assess the longterm consequences of the SARS-CoV-2 infection.

\section{CONCLUSION}

In this analysis, using multi-omics (proteome, transcriptome, interactome, and bibliome) data of SARS-CoV-2 infection and a unique bioinformatics strategy, we have identified mild and severe symptoms, associated comorbid conditions, short and long term complications of COVID-19. Based on available literature, our predictions are found to have $\sim 90 \%$ precision in identifying the COVID19 associated mild and severe symptoms, comorbid conditions, and long-haul complications. This indicates that the method we have developed is highly accurate and can be applied to other diseases and pandemics too. In this analysis, we have identified the disease/conditions using the omics profiles upregulated due to SARS-CoV-2 infection. Since the viral RNA remains active for several months within the COVID-19 survivors, these upregulated omics profile remains switched on for a long time and hence the corresponding NCD pathways may lead to the development of the respective NCD as a long-term consequence of SARS-CoV-2 infection. The limited literature on long-term consequences of COVID-19 so far available also supports our hypothesis. However, long-term observational studies are required to further support our findings.

\section{Author contribution}

DB: conceived and designed the experiment, data collection and analysis, result interpretation, and wrote the paper; ST and BSA preformed re-analysis; PG: data interpretation and edited the article, MEW, AGN, VA, NKG: provided technical inputs. All authors have read and approved the article.

\section{Funding}

None

\section{Competing interest}

Authors declare no competing interest. 
medRxiv preprint doi: https://doi.org/10.1101/2020.12.08.20245753; this version posted December 9, 2020. The copyright holder for this preprint (which was not certified by peer review) is the author/funder, who has granted medRxiv a license to display the preprint in It is made available under a CC-BY-NC-ND 4.0 International license .

\section{REFERENCES}

1. Zhu N, Zhang D, Wang W, Li X, Yang B, Song J, Zhao X, Huang B, Shi W, Lu R et al: A Novel Coronavirus from Patients with Pneumonia in China, 2019. N Engl J Med 2020, 382(8):727-733.

2. Wu F, Zhao S, Yu B, Chen YM, Wang W, Song ZG, Hu Y, Tao ZW, Tian JH, Pei YY et al: A new coronavirus associated with human respiratory disease in China. Nature 2020, 579(7798):265-269.

3. Chen N, Zhou M, Dong X, Qu J, Gong F, Han Y, Qiu Y, Wang J, Liu Y, Wei Y et al: Epidemiological and clinical characteristics of 99 cases of 2019 novel coronavirus pneumonia in Wuhan, China: a descriptive study. Lancet 2020, 395(10223):507-513.

4. WHO: COVID-19 Weekly Epidemiological Update. In.; 2020.

5. Alimohamadi Y, Sepandi M, Taghdir M, Hosamirudsari H: Determine the most common clinical symptoms in COVID-19 patients: a systematic review and meta-analysis. J Prev Med Hyg 2020, 61(3):E304-E312.

6. Vakili K, Fathi M, Pezeshgi A, Mohamadkhani A, Hajiesmaeili M, Rezaei-Tavirani M, Sayehmiri F: Critical complications of COVID-19: A descriptive meta-analysis study. Rev Cardiovasc Med 2020, 21(3):433-442.

7. Mizrahi B, Shilo S, Rossman H, Kalkstein N, Marcus K, Barer Y, Keshet A, Shamir-Stein Na, Shalev V, Ekka Zohar A et al: Longitudinal symptom dynamics of COVID-19 infection in primary care. medRxiv 2020.

8. Radwan NM, Mahmoud NE, Alfaifi AH, Alabdulkareem KI: Comorbidities and severity of coronavirus disease 2019 patients. Saudi Med J 2020, 41(11):1165-1174.

9. Javanmardi F, Keshavarzi A, Akbari A, Emami A, Pirbonyeh N: Prevalence of underlying diseases in died cases of COVID-19: A systematic review and meta-analysis. PLoS One 2020, 15(10):e0241265.

10. Wang Y, Chen J, Chen W, Liu L, Dong M, Ji J, Hu D, Zhang N: Does Asthma Increase the Mortality of Patients with COVID-19?: A Systematic Review and Meta-Analysis. Int Arch Allergy Immunol 2020:1-7.

11. Wu ZH, Yang DL: A meta-analysis of the impact of COVID-19 on liver dysfunction. Eur J Med Res 2020 , 25(1):54.

12. Iavarone M, D'Ambrosio R, Soria A, Triolo M, Pugliese N, Del Poggio P, Perricone G, Massironi S, Spinetti A, Buscarini E et al: High rates of 30-day mortality in patients with cirrhosis and COVID-19. J Hepatol 2020, 73(5):1063-1071.

13. Awortwe C, Cascorbi I: Meta-analysis on outcome-worsening comorbidities of COVID-19 and related potential drug-drug interactions. Pharmacol Res 2020:105250.

14. Morgante G, Troia L, De Leo V: Coronavirus Disease 2019 (SARS-CoV-2) and polycystic ovarian disease: Is there a higher risk for these women? J Steroid Biochem Mol Biol 2020, 205:105770.

15. Clark A, Jit M, Warren-Gash C, Guthrie B, Wang HHX, Mercer SW, Sanderson C, McKee M, Troeger C, Ong KL et al: Global, regional, and national estimates of the population at increased risk of severe COVID-19 due to underlying health conditions in 2020: a modelling study. Lancet Glob Health 2020, 8(8):e1003e1017.

16. Mudatsir M, Fajar JK, Wulandari L, Soegiarto G, Ilmawan M, Purnamasari Y, Mahdi BA, Jayanto GD, Suhendra S, Setianingsih YA et al: Predictors of COVID-19 severity: a systematic review and metaanalysis. F1000Res 2020, 9:1107.

17. Ebrahimi M, Malehi AS, Rahim F: COVID-19 Patients: A Systematic Review and Meta-Analysis of Laboratory Findings, Comorbidities, and Clinical Outcomes Comparing Medical Staff versus the General Population. Osong Public Health Res Perspect 2020, 11(5):269-279.

18. Carfi A, Bernabei R, Landi F, Gemelli Against C-P-ACSG: Persistent Symptoms in Patients After Acute COVID-19. JAMA 2020, 324(6):603-605.

19. Gupta A, Madhavan MV, Sehgal K, Nair N, Mahajan S, Sehrawat TS, Bikdeli B, Ahluwalia N, Ausiello JC, Wan EY et al: Extrapulmonary manifestations of COVID-19. Nat Med 2020, 26(7):1017-1032.

20. Scutari R, Piermatteo L, Ciancio Manuelli M, Iannetta M, Salpini R, Bertoli A, Alteri C, Saccomandi P, Bellocchi MC, Malagnino V et al: Long-Term SARS-CoV-2 Infection Associated with Viral Dissemination in Different Body Fluids Including Bile in Two Patients with Acute Cholecystitis. Life (Basel) 2020, 10(11).

21. Kamal M, Abo Omirah M, Hussein A, Saeed H: Assessment and characterisation of post-COVID-19 manifestations. Int J Clin Pract 2020:e13746.

22. Del Rio C, Collins LF, Malani P: Long-term Health Consequences of COVID-19. JAMA 2020.

23. Cirulli ET, Schiabor Barrett KM, Riffle S, Bolze A, Neveux I, Dabe S, Grzymski JJ, Lu JT, Washington NL: Long-term COVID-19 symptoms in a large unselected population. medrxiv 2020.

24. van den Borst B, Peters JB, Brink M, Schoon Y, Bleeker-Rovers CP, Schers H, van Hees HWH, van Helvoort $\mathrm{H}$, van den Boogaard $\mathrm{M}$, van der Hoeven $\mathrm{H}$ et al: Comprehensive health assessment three months after recovery from acute COVID-19. Clin Infect Dis 2020.

25. Caronna E, Ballve A, Llaurado A, Gallardo VJ, Maria Ariton D, Lallana S, Maza SL, Gadea MO, Quibus L, Restrepo JL et al: Headache: A striking prodromal and persistent symptom, predictive of COVID-19 clinical evolution. Cephalalgia 2020, 40(13):1410-1421. 
medRxiv preprint doi: https://doi.org/10.1101/2020.12.08.20245753; this version posted December 9, 2020. The copyright holder for this preprint (which was not certified by peer review) is the author/funder, who has granted medRxiv a license to display the preprint in

perpetuity. perpetuity. 4.0 International license

26. Alhassan SM, Iqbal P, Fikrey L, Mohamed Ibrahim MI, Qamar MS, Chaponda M, Munir W: Post COVID 19 acute acalculous cholecystitis raising the possibility of underlying dysregulated immune response, a case report. Ann Med Surg (Lond) 2020, 60:434-437.

27. Gambini G, Savastano MC, Savastano A, De Vico U, Crincoli E, Cozzupoli MG, Culiersi C, Rizzo S: Ocular surface impairment after COVID-19: a cohort study. Cornea 2020.

28. Koumpa FS, Forde CT, Manjaly JG: Sudden irreversible hearing loss post COVID-19. BMJ Case Rep 2020, 13(11).

29. Novak P: Post COVID-19 syndrome associated with orthostatic cerebral hypoperfusion syndrome, small fiber neuropathy and benefit of immunotherapy: a case report. eNeurologicalSci 2020, 21:100276.

30. Hossain MM, Tasnim S, Sultana A, Faizah F, Mazumder H, Zou L, McKyer ELJ, Ahmed HU, Ma P: Epidemiology of mental health problems in COVID-19: a review. F1000Res 2020, 9:636.

31. WHO: What we know about Long-term effects of COVID-19. In.; 2020.

32. Dennis A, Wamil M, Kapur S, Alberts J, Badley AD, Decker GA, Rizza SA, Banerjee R, Banerjee A: Multiorgan impairment in low-risk individuals with long COVID. medrxiv 2020.

33. Rubino F, Amiel SA, Zimmet P, Alberti G, Bornstein S, Eckel RH, Mingrone G, Boehm B, Cooper ME, Chai Z et al: New-Onset Diabetes in Covid-19. N Engl J Med 2020, 383(8):789-790.

34. Taquet M, Luciano S, Geddes JR, Harrison PJ: Bidirectional associations between COVID-19 and psychiatric disorder: retrospective cohort studies of 62354 COVID-19 cases in the USA. Lancet Psychiatry 2020.

35. Nishiga M, Wang DW, Han Y, Lewis DB, Wu JC: COVID-19 and cardiovascular disease: from basic mechanisms to clinical perspectives. Nat Rev Cardiol 2020, 17(9):543-558.

36. Barh D, Tiwari S, Weener ME, Azevedo V, Goes-Neto A, Gromiha MM, Ghosh P: Multi-omics-based identification of SARS-CoV-2 infection biology and candidate drugs against COVID-19. Comput Biol Med 2020, 126:104051.

37. Gordon DE, Jang GM, Bouhaddou M, Xu J, Obernier K, White KM, O'Meara MJ, Rezelj VV, Guo JZ, Swaney DL et al: A SARS-CoV-2 protein interaction map reveals targets for drug repurposing. Nature 2020, 583(7816):459-468.

38. Bojkova D, Klann K, Koch B, Widera M, Krause D, Ciesek S, Cinatl J, Munch C: Proteomics of SARS-CoV2-infected host cells reveals therapy targets. Nature 2020, 583(7816):469-472.

39. Blanco-Melo D, Nilsson-Payant BE, Liu WC, Uhl S, Hoagland D, Moller R, Jordan TX, Oishi K, Panis M, Sachs D et al: Imbalanced Host Response to SARS-CoV-2 Drives Development of COVID-19. Cell 2020, 181(5):1036-1045 e1039.

40. Xiong Y, Liu Y, Cao L, Wang D, Guo M, Jiang A, Guo D, Hu W, Yang J, Tang Z et al: Transcriptomic characteristics of bronchoalveolar lavage fluid and peripheral blood mononuclear cells in COVID-19 patients. Emerg Microbes Infect 2020, 9(1):761-770.

41. Chen J, Bardes EE, Aronow BJ, Jegga AG: ToppGene Suite for gene list enrichment analysis and candidate gene prioritization. Nucleic Acids Res 2009, 37(Web Server issue):W305-311.

42. Kuleshov MV, Jones MR, Rouillard AD, Fernandez NF, Duan Q, Wang Z, Koplev S, Jenkins SL, Jagodnik KM, Lachmann A et al: Enrichr: a comprehensive gene set enrichment analysis web server 2016 update. Nucleic Acids Res 2016, 44(W1):W90-97.

43. Barh D, Tiwari S, Kumavath RN, Ghosh P, Azevedo V: Linking common non-coding RNAs of human lung cancer and M. tuberculosis. Bioinformation 2018, 14(6):337-345.

44. Xiang Z MC, Ruttenberg A, He Y. : Ontobee: A Linked Data Server and Browser for Ontology Terms. . In: Proceedings of the 2nd International Conference on Biomedical Ontologies (ICBO), : 2011; NY, USA.; 2011: 279-281.

45. Chauhan S: Comprehensive review of coronavirus disease 2019 (COVID-19). Biomed J 2020, 43(4):334340 .

46. ElGohary GM, Hashmi S, Styczynski J, Kharfan-Dabaja MA, Alblooshi RM, de la Camara R, Mohmed S, Alshaibani A, Cesaro S, Abd El-Aziz N et al: The risk and prognosis of COVID-19 infection in cancer patients: A systematic review and meta-analysis. Hematol Oncol Stem Cell Ther 2020.

47. Pranata R, Huang I, Lim MA, Wahjoepramono EJ, July J: Impact of cerebrovascular and cardiovascular diseases on mortality and severity of COVID-19-systematic review, meta-analysis, and meta-regression. J Stroke Cerebrovasc Dis 2020, 29(8):104949.

48. Yang J, Zheng Y, Gou X, Pu K, Chen Z, Guo Q, Ji R, Wang H, Wang Y, Zhou Y: Prevalence of comorbidities and its effects in patients infected with SARS-CoV-2: a systematic review and metaanalysis. Int J Infect Dis 2020, 94:91-95.

49. Ferri C, Giuggioli D, Raimondo V, L'Andolina M, Tavoni A, Cecchetti R, Guiducci S, Ursini F, Caminiti M, Varcasia $G$ et al: COVID-19 and rheumatic autoimmune systemic diseases: report of a large Italian patients series. Clin Rheumatol 2020, 39(11):3195-3204.

50. Akiyama S, Hamdeh S, Micic D, Sakuraba A: Prevalence and clinical outcomes of COVID-19 in patients with autoimmune diseases: a systematic review and meta-analysis. Ann Rheum Dis 2020.

51. Costa FF, Rosario WR, Ribeiro Farias AC, de Souza RG, Duarte Gondim RS, Barroso WA: Metabolic syndrome and COVID-19: An update on the associated comorbidities and proposed therapies. Diabetes Metab Syndr 2020, 14(5):809-814. 
medRxiv preprint doi: https://doi.org/10.1101/2020.12.08.20245753; this version posted December 9, 2020. The copyright holder for this preprint (which was not certified by peer review) is the author/funder, who has granted medRxiv a license to display the preprint in perpetuity.

52. Ayres JS: A metabolic handbook for the COVID-19 pandemic. Nat Metab 2020, 2(7):572-585.

53. Radke RM, Frenzel T, Baumgartner H, Diller GP: Adult congenital heart disease and the COVID-19 pandemic. Heart 2020, 106(17):1302-1309.

54. Alsaied T, Aboulhosn JA, Cotts TB, Daniels CJ, Etheridge SP, Feltes TF, Gurvitz MZ, Lewin MB, Oster ME, Saidi A: Coronavirus Disease 2019 (COVID-19) Pandemic Implications in Pediatric and Adult Congenital Heart Disease. J Am Heart Assoc 2020, 9(12):e017224.

Hunt RH, East JE, Lanas A, Malfertheiner P, Satsangi J, Scarpignato C, Webb GJ: COVID-19 and Gastrointestinal Disease. Implications for the Gastroenterologist. Dig Dis 2020.

56. Kunutsor SK, Laukkanen JA: Renal complications in COVID-19: a systematic review and meta-analysis. Ann Med 2020, 52(7):345-353.

57. Patel SK, Singh R, Rana J, Tiwari R, Natesan S, Harapan H, Arteaga-Livias K, Bonilla-Aldana DK, Rodriguez-Morales AJ, Dhama K: The kidney and COVID-19 patients - Important considerations. Travel Med Infect Dis 2020, 37:101831.

58. Metawea MI, Yousif WI, Moheb I: COVID 19 and liver: An A-Z literature review. Dig Liver Dis 2020.

59. Debuc B, Smadja DM: Is COVID-19 a New Hematologic Disease? Stem Cell Rev Rep 2020.

60. Beltran-Garcia J, Osca-Verdegal R, Pallardo FV, Ferreres J, Rodriguez M, Mulet S, Ferrando-Sanchez C, Carbonell N, Garcia-Gimenez JL: Sepsis and Coronavirus Disease 2019: Common Features and AntiInflammatory Therapeutic Approaches. Crit Care Med 2020, 48(12):1841-1844.

61. Koralnik IJ, Tyler KL: COVID-19: A Global Threat to the Nervous System. Ann Neurol 2020, 88(1):1-11.

62. Ellul MA, Benjamin L, Singh B, Lant S, Michael BD, Easton A, Kneen R, Defres S, Sejvar J, Solomon T: Neurological associations of COVID-19. Lancet Neurol 2020, 19(9):767-783.

63. Cipollaro L, Giordano L, Padulo J, Oliva F, Maffulli N: Musculoskeletal symptoms in SARS-CoV-2 (COVID-19) patients. J Orthop Surg Res 2020, 15(1):178.

64. Disser NP, De Micheli AJ, Schonk MM, Konnaris MA, Piacentini AN, Edon DL, Toresdahl BG, Rodeo SA, Casey EK, Mendias CL: Musculoskeletal Consequences of COVID-19. J Bone Joint Surg Am 2020, 102(14):1197-1204.

65. Li R, Yin T, Fang F, Li Q, Chen J, Wang Y, Hao Y, Wu G, Duan P, Wang Y et al: Potential risks of SARSCoV-2 infection on reproductive health. Reprod Biomed Online 2020, 41(1):89-95.

66. Zupin L, Pascolo L, Zito G, Ricci G, Crovella S: SARS-CoV-2 and the next generations: which impact on reproductive tissues? J Assist Reprod Genet 2020, 37(10):2399-2403.

67. Nuzzi R, Carucci LL, Tripoli F: COVID-19 and ocular implications: an update. J Ophthalmic Inflamm Infect 2020, 10(1):20.

68. Marraha F, Al Faker I, Gallouj S: A Review of the Dermatological Manifestations of Coronavirus Disease 2019 (COVID-19). Dermatol Res Pract 2020, 2020:9360476.

69. Sameni F, Hajikhani B, Yaslianifard S, Goudarzi M, Owlia P, Nasiri MJ, Shokouhi S, Bakhtiyari M, Dadashi M: COVID-19 and Skin Manifestations: An Overview of Case Reports/Case Series and Meta-Analysis of Prevalence Studies. Frontiers in Medicine 2020, 7.

70. Gao YJ, Ye L, Zhang JS, Yin YX, Liu M, Yu HB, Zhou R: Clinical features and outcomes of pregnant women with COVID-19: a systematic review and meta-analysis. BMC Infect Dis 2020, 20 (1):564.

71. Siddiqi HK, Libby P, Ridker PM: COVID-19 - A vascular disease. Trends Cardiovasc Med 2020.

Ferini-Strambi L, Salsone M: COVID-19 and neurological disorders: are neurodegenerative or neuroimmunological diseases more vulnerable? J Neurol 2020.

73. Roongta R, Ghosh A: Managing rheumatoid arthritis during COVID-19. Clin Rheumatol 2020, 39(11):3237-3244.

74. Mitrani RD, Dabas N, Goldberger JJ: COVID-19 cardiac injury: Implications for long-term surveillance and outcomes in survivors. Heart Rhythm 2020, 17(11):1984-1990.

75. Madan A, Siglin J, Khan A: Comprehensive review of implications of COVID-19 on clinical outcomes of cancer patients and management of solid tumors during the pandemic. Cancer Med 2020.

76. Lara OD, O'Cearbhaill RE, Smith MJ, Sutter ME, Knisely A, McEachron J, Gabor LR, Jee J, Fehniger JE, Lee YC et al: COVID-19 outcomes of patients with gynecologic cancer in New York City. Cancer 2020.

77. To T, Viegi G, Cruz A, Taborda-Barata L, Asher I, Behera D, Bennoor K, Boulet LP, Bousquet J, Camargos P et al: A global respiratory perspective on the COVID-19 pandemic: commentary and action proposals. Eur Respir J 2020, 56(1).

78. Chan SL, Kudo M: Impacts of COVID-19 on Liver Cancers: During and after the Pandemic. Liver Cancer 2020, 9(5):491-502.

79. Wang Q, Berger NA, Xu R: When hematologic malignancies meet COVID-19 in the United States: Infections, death and disparities. Blood Rev 2020:100775.

80. Ramlall V, Thangaraj PM, Meydan C, Foox J, Butler D, Kim J, May B, De Freitas JK, Glicksberg BS, Mason $\mathrm{CE}$ et al: Immune complement and coagulation dysfunction in adverse outcomes of SARS-CoV-2 infection. Nat Med 2020, 26(10):1609-1615.

81. Dallan C, Romano F, Siebert J, Politi S, Lacroix L, Sahyoun C: Septic shock presentation in adolescents with COVID-19. Lancet Child Adolesc Health 2020, 4(7):e21-e23.

82. Miller LE, Bhattacharyya R, Miller AL: Diabetes mellitus increases the risk of hospital mortality in patients with Covid-19: Systematic review with meta-analysis. Medicine (Baltimore) 2020, 99(40):e22439. 
medRxiv preprint doi: https://doi.org/10.1101/2020.12.08.20245753; this version posted December 9, 2020. The copyright holder for this preprint (which was not certified by peer review) is the author/funder, who has granted medRxiv a license to display the preprint in perpetuity. perpetuity. 4.0 International license.

83. Garg RK, Paliwal VK, Gupta A: Encephalopathy in patients with COVID-19: A review. J Med Virol 2020.

84. Ho HE, Mathew S, Peluso MJ, Cunningham-Rundles C: Clinical outcomes and features of COVID-19 in patients with primary immunodeficiencies in New York City. J Allergy Clin Immunol Pract 2020.

85. Paterson RW, Brown RL, Benjamin L, Nortley R, Wiethoff S, Bharucha T, Jayaseelan DL, Kumar G, Raftopoulos RE, Zambreanu L et al: The emerging spectrum of COVID-19 neurology: clinical, radiological and laboratory findings. Brain 2020, 143(10):3104-3120.

86. Leung JM, Niikura M, Yang CWT, Sin DD: COVID-19 and COPD. Eur Respir J 2020, 56(2).

87. Antikchi MH, Neamatzadeh H, Ghelmani Y, Jafari-Nedooshan J, Dastgheib SA, Kargar S, Noorishadkam M, Bahrami R, Jarahzadeh MH: The Risk and Prevalence of COVID-19 Infection in Colorectal Cancer Patients: a Systematic Review and Meta-analysis. J Gastrointest Cancer 2020.

88. Colizzi M, Sironi E, Antonini F, Ciceri ML, Bovo C, Zoccante L: Psychosocial and Behavioral Impact of COVID-19 in Autism Spectrum Disorder: An Online Parent Survey. Brain Sci 2020, 10(6).

89. Lima MES, Barros LCM, Aragao GF: Could autism spectrum disorders be a risk factor for COVID-19? Med Hypotheses 2020, 144:109899.

90. Hariyanto TI, Kurniawan A: Anemia is associated with severe coronavirus disease 2019 (COVID-19) infection. Transfus Apher Sci 2020:102926.

91. Girgis CM, Clifton-Bligh RJ: Osteoporosis in the age of COVID-19. Osteoporos Int 2020, 31(7):1189-1191.

92. Radenkovic D, Chawla S, Pirro M, Sahebkar A, Banach M: Cholesterol in Relation to COVID-19: Should We Care about It? J Clin Med 2020, 9(6).

93. Wei X, Zeng W, Su J, Wan H, Yu X, Cao X, Tan W, Wang H: Hypolipidemia is associated with the severity of COVID-19. J Clin Lipidol 2020, 14(3):297-304.

94. Mukherjee D, Sarkar P, Dubey S, Ray BK, Pandit A, Lahiri D: Ataxia as a presenting manifestation of COVID -19: Report of a single case. medRxiv 2020.

95. Macaluso FS, Orlando A: COVID-19 in patients with inflammatory bowel disease: A systematic review of clinical data. Dig Liver Dis 2020, 52(11):1222-1227.

96. Mo X, Jian W, Su Z, Chen M, Peng H, Peng P, Lei C, Chen R, Zhong N, Li S: Abnormal pulmonary function in COVID-19 patients at time of hospital discharge. Eur Respir J 2020, 55(6).

97. Zhao YM, Shang YM, Song WB, Li QQ, Xie H, Xu QF, Jia JL, Li LM, Mao HL, Zhou XM et al: Follow-up study of the pulmonary function and related physiological characteristics of COVID-19 survivors three months after recovery. EClinicalMedicine 2020, 25:100463.

98. Miller MA, Cappuccio FP: A systematic review of COVID-19 and obstructive sleep apnoea. Sleep Med Rev 2020, 55:101382.

99. Guemes-Villahoz N, Burgos-Blasco B, Garcia-Feijoo J, Saenz-Frances F, Arriola-Villalobos P, Martinez-dela-Casa JM, Benitez-Del-Castillo JM, Herrera de la Muela M: Conjunctivitis in COVID-19 patients: frequency and clinical presentation. Graefes Arch Clin Exp Ophthalmol 2020, 258(11):2501-2507.

100. Spihlman AP, Gadi N, Wu SC, Moulton VR: COVID-19 and Systemic Lupus Erythematosus: Focus on Immune Response and Therapeutics. Front Immunol 2020, 11:589474.

101. Steardo L, Jr., Steardo L, Verkhratsky A: Psychiatric face of COVID-19. Transl Psychiatry 2020, 10(1):261.

102. Mirzaie H, Vahidi M, Shokoohi M, Darvishian M, Sharifi H, Sharafi H, Karamouzian M: COVID-19 among patients with hepatitis B or hepatitis C: A systematic review. medrxiv 2020.

103. Abualfadl E, Ismail F, Shereef RRE, Hassan E, Tharwat S, Mohamed EF, Abda EA, Radwan AR, Fawzy RM, Moshrif AH et al: Impact of COVID-19 pandemic on rheumatoid arthritis from a Multi-Centre patientreported questionnaire survey: influence of gender, rural-urban gap and north-south gradient. Rheumatol Int 2020.

104. Tadolini M, Codecasa LR, Garcia-Garcia JM, Blanc FX, Borisov S, Alffenaar JW, Andrejak C, Bachez P, Bart PA, Belilovski E et al: Active tuberculosis, sequelae and COVID-19 co-infection: first cohort of 49 cases. Eur Respir J 2020, 56(1).

105. Motta I, Centis R, D'Ambrosio L, Garcia-Garcia JM, Goletti D, Gualano G, Lipani F, Palmieri F, SanchezMontalva A, Pontali E et al: Tuberculosis, COVID-19 and migrants: Preliminary analysis of deaths occurring in 69 patients from two cohorts. Pulmonology 2020, 26(4):233-240.

106. Lang JP, Wang X, Moura FA, Siddiqi HK, Morrow DA, Bohula EA: A current review of COVID-19 for the cardiovascular specialist. Am Heart J 2020, 226:29-44.

107. Dillinger JG, Benmessaoud FA, Pezel T, Voicu S, Sideris G, Chergui N, Hamzi L, Chauvin A, Leroy P, Gautier JF et al: Coronary Artery Calcification and Complications in Patients With COVID-19. JACC Cardiovasc Imaging 2020, 13(11):2468-2470.

108. D'Amico F, Danese S, Peyrin-Biroulet L: Systematic Review on Inflammatory Bowel Disease Patients With Coronavirus Disease 2019: It Is Time to Take Stock. Clin Gastroenterol Hepatol 2020, 18(12):26892700.

109. Marjot T, Moon AM, Cook JA, Abd-Elsalam S, Aloman C, Armstrong MJ, Pose E, Brenner EJ, Cargill T, Catana MA et al: Outcomes following SARS-CoV-2 infection in patients with chronic liver disease: an international registry study. J Hepatol 2020.

110. Lee KW, Yusof Khan AHK, Ching SM, Chia PK, Loh WC, Abdul Rashid AM, Baharin J, Inche Mat LN, Wan Sulaiman WA, Devaraj NK et al: Stroke and Novel Coronavirus Infection in Humans: A Systematic Review and Meta-Analysis. Front Neurol 2020, 11:579070. 
medRxiv preprint doi: https://doi.org/10.1101/2020.12.08.20245753; this version posted December 9, 2020. The copyright holder for this

preprint (which was not certified by peer review) is the author/funder, who has granted medRxiv a license to display the preprint in

It is made available under a CC-BY-NC-ND 4.0 International license .

111. Kehinde TA, Osundiji MA: Sickle cell trait and the potential risk of severe coronavirus disease 2019-A mini-review. Eur J Haematol 2020.

112. Dhakal B, D'Souza A, Chhabra S, Hari P: Multiple myeloma and COVID-19. Leukemia 2020, 34(7):19611963.

113. de Almeida-Pititto B, Dualib PM, Zajdenverg L, Dantas JR, de Souza FD, Rodacki M, Bertoluci MC, Brazilian Diabetes Society Study G: Severity and mortality of COVID 19 in patients with diabetes, hypertension and cardiovascular disease: a meta-analysis. Diabetol Metab Syndr 2020, 12:75.

114. Xie J, Zu Y, Alkhatib A, Pham TT, Gill F, Jang A, Radosta S, Chaaya G, Myers L, Zifodya JS et al: Metabolic Syndrome and COVID-19 Mortality Among Adult Black Patients in New Orleans. Diabetes Care 2020.

115. Dovey Z, Mohamed N, Gharib Y, Ratnani P, Hammouda N, Nair SS, Chakravarty D, Sobotka S, Lantz A, Wiklund P et al: Impact of COVID-19 on Prostate Cancer Management: Guidelines for Urologists. European Urology Open Science 2020, 20:1-11.

116. Kutlu O, Metin A: Dermatological diseases presented before COVID-19: Are patients with psoriasis and superficial fungal infections more vulnerable to the COVID-19? Dermatol Ther 2020, 33(4):e13509.

117. Mato AR, Roeker LE, Lamanna N, Allan JN, Leslie L, Pagel JM, Patel K, Osterborg A, Wojenski D, Kamdar $\mathrm{M}$ et al: Outcomes of COVID-19 in patients with CLL: a multicenter international experience. Blood 2020, 136(10):1134-1143.

118. Scarfo L, Chatzikonstantinou T, Rigolin GM, Quaresmini G, Motta M, Vitale C, Garcia-Marco JA, Hernandez-Rivas JA, Miras F, Baile M et al: COVID-19 severity and mortality in patients with chronic lymphocytic leukemia: a joint study by ERIC, the European Research Initiative on CLL, and CLL Campus. Leukemia 2020, 34(9):2354-2363.

119. Wu C-I, Postema PG, Arbelo E, Behr ER, Bezzina CR, Napolitano C, Robyns T, Probst V, Schulze-Bahr E, Remme CA et al: SARS-CoV-2, COVID-19, and inherited arrhythmia syndromes. Heart Rhythm 2020, 17(9):1456-1462.

120. Reyes-Bueno JA, Mena-Vázquez N, Ojea-Ortega T, Gonzalez-Sotomayor MM, Cabezudo-Garcia P, CianoPetersen NL, Pons-Pons G, Castro-Sánchez MV, Serrano-Castro PJ: Análisis de letalidad por COVID-19 en pacientes con demencia neurodegenerativa. Neurología 2020, 35(9):639-645.

121. Fonseca L, Diniz E, Mendonça G, Malinowski F, Mari J, Gadelha A: Schizophrenia and COVID-19: risks and recommendations. Brazilian Journal of Psychiatry 2020, 42(3):236-238.

122. Perera B, Laugharne R, Henley W, Zabel A, Lamb K, Branford D, Courtanay K, Alexander R, Purandare K, Wijeratne A et al: COVID-19 deaths in people with intellectual disability in the UK and Ireland: descriptive study. BJPsych Open 2020, 6(6).

123. Turk MA, Landes SD, Formica MK, Goss KD: Intellectual and developmental disability and COVID-19 case-fatality trends: TriNetX analysis. Disability and Health Journal 2020, 13(3).

124. Leon-Abarca JA, Memon RS, Rehan B, Iftikhar M, Chatterjee A: The impact of COVID-19 in diabetic kidney disease and chronic kidney disease: A population-based study. medrxiv 2020.

125. Cooper TJ, Woodward BL, Alom S, Harky A: Coronavirus disease 2019 (COVID-19) outcomes in HIV/AIDS patients: a systematic review. HIV Med 2020.

126. Fan M, Qiu W, Bu B, Xu Y, Yang H, Huang D, Lau AY, Guo J, Zhang MN, Zhang X et al: Risk of COVID19 infection in MS and neuromyelitis optica spectrum disorders. Neurol Neuroimmunol Neuroinflamm 2020, 7(5).

127. Keswani A, Dhana K, Rosenthal JA, Moore D, Mahdavinia M: Atopy is predictive of a decreased need for hospitalization for coronavirus disease 2019. Ann Allergy Asthma Immunol 2020, 125(4):479-481.

128. Scala E, Abeni D, Tedeschi A, Manzotti G, Yang B, Borrelli P, Marra A, Giani M, Sgadari A, Saltalamacchia F et al: Atopic status protects from severe complications of COVID-19. Allergy 2020.

129. Song X, Delaney M, Shah RK, Campos JM, Wessel DL, DeBiasi RL: Comparison of Clinical Features of COVID-19 vs Seasonal Influenza A and B in US Children. JAMA Netw Open 2020, 3(9):e2020495.

130. Henrina J, Putra ICS, Lawrensia S, Handoyono QF, Cahyadi A: Coronavirus Disease of 2019: a Mimicker of Dengue Infection? SN Compr Clin Med 2020:1-11.

131. Gokhale Y, Patankar A, Holla U, Shilke M, Kalekar L, Karnik ND, Bidichandani K, Baveja S, Joshi A: Dermatomyositis during COVID-19 Pandemic (A Case Series): Is there a Cause Effect Relationship? J Assoc Physicians India 2020, 68(11):20-24.

132. Kermani-Alghoraishi M, Ghahramani R: A Review of Venous Thromboembolism Phenomena in COVID19 Patients. Curr Probl Cardiol 2020:100692.

133. Perez-Suarez B, Martinez-Menchon T, Cutillas-Marco E: Skin findings in the COVID-19 pandemic in the Region of Murcia. Med Clin (Engl Ed) 2020, 155(1):41-42.

134. Lechien JR, Chiesa-Estomba CM, Cabaraux P, Mat Q, Huet K, Harmegnies B, Horoi M, Le Bon SD, Rodriguez A, Dequanter D et al: Features of Mild-to-Moderate COVID-19 Patients With Dysphonia. $J$ Voice 2020.

135. Mazza MG, De Lorenzo R, Conte C, Poletti S, Vai B, Bollettini I, Melloni EMT, Furlan R, Ciceri F, RovereQuerini $\mathrm{P}$ et al: Anxiety and depression in COVID-19 survivors: Role of inflammatory and clinical predictors. Brain Behav Immun 2020, 89:594-600. 
medRxiv preprint doi: https://doi.org/10.1101/2020.12.08.20245753; this version posted December 9, 2020. The copyright holder for this preprint (which was not certified by peer review) is the author/funder, who has granted medRxiv a license to display the preprint in

It is made available under a perpetuity.

136. Pirzada A, Mokhtar AT, Moeller AD: COVID-19 and Myocarditis: What Do We Know So Far? CJC Open 2020, 2(4):278-285.

137. Sawalha K, Abozenah M, Kadado AJ, Battisha A, Al-Akchar M, Salerno C, Hernandez-Montfort J, Islam AM: Systematic review of COVID-19 related myocarditis: Insights on management and outcome. Cardiovasc Revasc Med 2020.

138. Muhammad S, Petridis A, Cornelius JF, Hanggi D: Letter to editor: Severe brain haemorrhage and concomitant COVID-19 Infection: A neurovascular complication of COVID-19. Brain Behav Immun 2020, 87:150-151.

139. Beydon M, Chevalier K, Al Tabaa O, Hamroun S, Delettre AS, Thomas M, Herrou J, Riviere E, Mariette X: Myositis as a manifestation of SARS-CoV-2. Ann Rheum Dis 2020.

140. WHO: COVID-19 affects different people in different ways. Most infected people will develop mild to moderate illness and recover without hospitalization. In.; 2020.

141. Zayet S, Kadiane-Oussou NJ, Lepiller Q, Zahra H, Royer PY, Toko L, Gendrin V, Klopfenstein T: Clinical features of COVID-19 and influenza: a comparative study on Nord Franche-Comte cluster. Microbes Infect 2020, 22(9):481-488.

142. Singhal T: A Review of Coronavirus Disease-2019 (COVID-19). Indian J Pediatr 2020, 87(4):281-286.

143. Chanda-Kapata P, Kapata N, Zumla A: COVID-19 and malaria: A symptom screening challenge for malaria endemic countries. Int J Infect Dis 2020, 94:151-153.

144. Bao C, Tao X, Cui W, Yi B, Pan T, Young KH, Qian W: SARS-CoV-2 induced thrombocytopenia as an important biomarker significantly correlated with abnormal coagulation function, increased intravascular blood clot risk and mortality in COVID-19 patients. Exp Hematol Oncol 2020, 9:16.

145. Assari S: COVID-19 Pandemic and Neurological Disease: A Critical Review of the Existing Literature. Hosp Pract Res 2020, 5(3):81-86.

146. Tolebeyan AS, Zhang N, Cooper V, Kuruvilla DE: Headache in Patients With Severe Acute Respiratory Syndrome Coronavirus 2 Infection: A Narrative Review. Headache 2020, 60(10):2131-2138.

147. Wang C, Zhang H, Cao X, Deng R, Ye Y, Fu Z, Gou L, Shao F, Li J, Fu W et al: Red cell distribution width (RDW): a prognostic indicator of severe COVID-19. Ann Transl Med 2020, 8(19):1230.

148. Li Y, Jiang Y, Zhang Y, Li N, Yin Q, Liu L, Lv X, Liu Y, Li A, Fang B et al: Abnormal Upregulation of Cardiovascular Disease Biomarker PLA2G7 Induced by Proinflammatory Macrophages in COVID-19 patients. medrxiv 2020.

149. Ferrari E, Sartre B, Squara F, Contenti J, Occelli C, Lemoel F, Levraut J, Doyen D, Dellamonica J, Mondain V et al: High Prevalence of Acquired Thrombophilia Without Prognosis Value in Patients With Coronavirus Disease 2019. J Am Heart Assoc 2020, 9(21):e017773.

150. Gueant JL, Fromonot J, Gueant-Rodriguez RM, Lacolley P, Guieu R, Regnault V: Blood MyeloperoxidaseDNA, a biomarker of early response to SARS-CoV-2 infection? Allergy 2020.

151. Wang L: C-reactive protein levels in the early stage of COVID-19. Med Mal Infect 2020, 50(4):332-334.

152. Hantoushzadeh S, Norooznezhad AH: Possible Cause of Inflammatory Storm and Septic Shock in Patients Diagnosed with (COVID-19). Arch Med Res 2020, 51(4):347-348.

153. Ueland T, Holter JC, Holten AR, Muller KE, Lind A, Bekken GK, Dudman S, Aukrust P, Dyrhol-Riise AM, Heggelund L: Distinct and early increase in circulating MMP-9 in COVID-19 patients with respiratory failure. J Infect 2020, 81(3):e41-e43.

154. Fondaw A, Arshad M, Batool S, Robinson B, Patel T: COVID-19 infection presenting with acute epiglottitis. J Surg Case Rep 2020, 2020(9):rjaa280.

155. Naz S, Hanif M, Haider MA, Ali MJ, Ahmed MU, Saleem S: Meningitis as an Initial Presentation of COVID-19: A Case Report. Front Public Health 2020, 8:474.

156. Fidan V: New type of corona virus induced acute otitis media in adult. Am J Otolaryngol 2020, 41(3): 102487.

157. Paliogiannis P, Zinellu A: Bilirubin levels in patients with mild and severe Covid-19: A pooled analysis. Liver Int 2020, 40(7):1787-1788.

158. Zuo Y, Warnock M, Harbaugh A, Yalavarthi S, Gockman K, Zuo M, Madison JA, Knight JS, Kanthi Y, Lawrence DA: Plasma tissue plasminogen activator and plasminogen activator inhibitor-1 in hospitalized COVID-19 patients. medRxiv 2020.

159. Taneri PE, Gomez-Ochoa SA, Llanaj E, Raguindin PF, Rojas LZ, Roa-Diaz ZM, Salvador D, Jr., Groothof D, Minder B, Kopp-Heim D et al: Anemia and iron metabolism in COVID-19: a systematic review and metaanalysis. Eur J Epidemiol 2020, 35(8):763-773.

160. Elkattawy S, Alyacoub R, Ayad S, Pandya M, Eckman A: A Novel Case of Hypoparathyroidism Secondary to SARS-CoV-2 Infection. Cureus 2020, 12(8):e10097.

161. Sun JK, Zhang WH, Zou L, Liu Y, Li JJ, Kan XH, Dai L, Shi QK, Yuan ST, Yu WK et al: Serum calcium as a biomarker of clinical severity and prognosis in patients with coronavirus disease 2019. Aging (Albany NY) 2020, 12(12):11287-11295.

162. Hao SR, Zhang SY, Lian JS, Jin X, Ye CY, Cai H, Zhang XL, Hu JH, Zheng L, Zhang YM et al: Liver Enzyme Elevation in Coronavirus Disease 2019: A Multicenter, Retrospective, Cross-Sectional Study. Am J Gastroenterol 2020, 115(7):1075-1083. 
medRxiv preprint doi: https://doi.org/10.1101/2020.12.08.20245753; this version posted December 9, 2020. The copyright holder for this preprint (which was not certified by peer review) is the author/funder, who has granted medRxiv a license to display the preprint in

It is made available underpetuity.

perpetuity. 4.0 International license

163. Willcox MD, Walsh K, Nichols JJ, Morgan PB, Jones LW: The ocular surface, coronaviruses and COVID19. Clin Exp Optom 2020, 103(4):418-424.

164. Chegondi M, Kothari H, Chacham S, Badheka A: Coronavirus Disease 2019 (COVID-19) Associated With Febrile Status Epilepticus in a Child. Cureus 2020, 12(8):e9840.

165. Asadi-Pooya AA: Seizures associated with coronavirus infections. Seizure 2020, 79:49-52.

166. Turbin RE, Wawrzusin PJ, Sakla NM, Traba CM, Wong KG, Mirani N, Eloy JA, Nimchinsky EA: Orbital cellulitis, sinusitis and intracranial abnormalities in two adolescents with COVID-19. Orbit 2020, 39(4):305-310.

167. Pal R, Bhadada SK: COVID-19 and diabetes mellitus: An unholy interaction of two pandemics. Diabetes Metab Syndr 2020, 14(4):513-517.

168. Berzuini A, Bianco C, Migliorini AC, Maggioni M, Valenti L, Prati D: Red blood cell morphology in patients with COVID-19-related anaemia. Blood Transfus 2020.

169. Melazzini F, Lenti MV, Mauro A, De Grazia F, Di Sabatino A: Peptic Ulcer Disease as a Common Cause of Bleeding in Patients with Coronavirus Disease 2019. Am J Gastroenterol 2020, 115(7):1139-1140.

170. Rajkumar RP: COVID-19 and mental health: A review of the existing literature. Asian J Psychiatr 2020 , 52:102066.

171. Rogers JP, Chesney E, Oliver D, Pollak TA, McGuire P, Fusar-Poli P, Zandi MS, Lewis G, David AS: Psychiatric and neuropsychiatric presentations associated with severe coronavirus infections: a systematic review and meta-analysis with comparison to the COVID-19 pandemic. Lancet Psychiatry 2020, 7(7):611-627.

172. Nakase H, Matsumoto T, Matsuura M, Iijima H, Matsuoka K, Ohmiya N, Ishihara S, Hirai F, Wagatsuma K, Yokoyama Y et al: Expert Opinions on the Current Therapeutic Management of Inflammatory Bowel Disease during the COVID-19 Pandemic: Japan IBD COVID-19 Taskforce, Intractable Diseases, the Health and Labor Sciences Research. Digestion 2020:1-9.

173. Li Y, Li M, Wang M, Zhou Y, Chang J, Xian Y, Wang D, Mao L, Jin H, Hu B: Acute cerebrovascular disease following COVID-19: a single center, retrospective, observational study. Stroke Vasc Neurol 2020, 5(3):279-284.

174. Kumar R, Kumar J, Daly C, Edroos SA: Acute pericarditis as a primary presentation of COVID-19. BMJ Case Rep 2020, 13(8).

175. Ojo AS, Balogun SA, Williams OT, Ojo OS: Pulmonary Fibrosis in COVID-19 Survivors: Predictive Factors and Risk Reduction Strategies. Pulm Med 2020, 2020:6175964.

176. Ding T, Zhang J, Wang T, Cui P, Chen Z, Jiang J, Zhou S, Dai J, Wang B, Yuan S et al: A Multi-hospital Study in Wuhan, China: Protective Effects of Non-menopause and Female Hormones on SARS-CoV-2 infection. medrxiv 2020.

177. Gansevoort RT, Hilbrands LB: CKD is a key risk factor for COVID-19 mortality. Nat Rev Nephrol 2020, 16(12):705-706.

178. Nadim MK, Forni LG, Mehta RL, Connor MJ, Jr., Liu KD, Ostermann M, Rimmele T, Zarbock A, Bell S, Bihorac A et al: COVID-19-associated acute kidney injury: consensus report of the 25th Acute Disease Quality Initiative (ADQI) Workgroup. Nat Rev Nephrol 2020, 16(12):747-764.

179. Guadarrama-Ortiz P, Choreno-Parra JA, Sanchez-Martinez CM, Pacheco-Sanchez FJ, Rodriguez-Nava AI, Garcia-Quintero G: Neurological Aspects of SARS-CoV-2 Infection: Mechanisms and Manifestations. Front Neurol 2020, 11:1039.

180. Aksan F, Nelson EA, Swedish KA: A COVID-19 patient with intense burning pain. J Neurovirol 2020, 26(5):800-801.

181. Wang F, Kream RM, Stefano GB: Long-Term Respiratory and Neurological Sequelae of COVID-19. Med Sci Monit 2020, 26:e928996.

182. Pretorius E, Venter C, Laubscher GJ, Lourens PJ, Steenkamp J, Kell DB: Prevalence of amyloid blood clots in COVID-19 plasma. medrxiv 2020.

183. Goncalves CA, Sesterheim P: Serum amyloid A protein has been undervalued as a biomarker of COVID19. Diabetes Metab Res Rev 2020:e3376.

184. Pensato U, Muccioli L, Pasini E, Tappata M, Ferri L, Volpi L, Licchetta L, Battaglia S, Rossini G, Bon I et al: Encephalopathy in COVID-19 Presenting With Acute Aphasia Mimicking Stroke. Front Neurol 2020, 11:587226.

185. Priftis K, Algeri L, Villella S, Spada MS: COVID-19 presenting with agraphia and conduction aphasia in a patient with left-hemisphere ischemic stroke. Neurol Sci 2020, 41(12):3381-3384.

186. Atkins JL, Masoli JAH, Delgado J, Pilling LC, Kuo CL, Kuchel GA, Melzer D: Preexisting Comorbidities Predicting COVID-19 and Mortality in the UK Biobank Community Cohort. J Gerontol A Biol Sci Med Sci 2020, 75(11):2224-2230.

187. Brown EE, Kumar S, Rajji TK, Pollock BG, Mulsant BH: Anticipating and Mitigating the Impact of the COVID-19 Pandemic on Alzheimer's Disease and Related Dementias. Am J Geriatr Psychiatry 2020, 28(7):712-721.

188. Khan I, Hatiboglu MA: Can COVID-19 induce glioma tumorogenesis through binding cell receptors? Med Hypotheses 2020, 144:110009. 
medRxiv preprint doi: https://doi.org/10.1101/2020.12.08.20245753; this version posted December 9,2020 . The copyright holder for this preprint (which was not certified by peer review) is the author/funder, who has granted medRxiv a license to display the preprint in It is made available under a perpetuity.

189. Wang QQ, Kaelber DC, Xu R, Volkow ND: COVID-19 risk and outcomes in patients with substance use disorders: analyses from electronic health records in the United States. Mol Psychiatry 2020.

190. Gillett G, Jordan I: Severe psychiatric disturbance and attempted suicide in a patient with COVID-19 and no psychiatric history. BMJ Case Rep 2020, 13(10).

191. Morales-Sanchez A, Fuentes-Panana EM: Human viruses and cancer. Viruses 2014, 6(10):4047-4079.

192. Krump NA, You J: Molecular mechanisms of viral oncogenesis in humans. Nature Reviews Microbiology 2018, 16(11):684-698.

193. Clift AK, Coupland CAC, Keogh RH, Hemingway H, Hippisley-Cox J: COVID-19 Mortality Risk in Down Syndrome: Results From a Cohort Study Of 8 Million Adults. Ann Intern Med 2020.

194. Dorgalaleh A, Tabibian S, Mohammadamini M, Bahraini M, Dabbagh A, Noroozi-Aghideh A, Shams M, Anvar A, Namvar A, Baghaipour MR et al: Do congenital bleeding disorders have a protective effect against COVID-19? A prospective study. Int J Lab Hematol 2020.

195. Rawat M, Chandrasekharan P, Hicar MD, Lakshminrusimha S: COVID-19 in Newborns and Infants-Low Risk of Severe Disease: Silver Lining or Dark Cloud? Am J Perinatol 2020, 37(8):845-849.

196. Sotoudeh E, Sotoudeh H: A hypothesis about the role of fetal hemoglobin in COVID-19. Med Hypotheses 2020, 144:109994.

197. Colombo C, Burgel PR, Gartner S, van Koningsbruggen-Rietschel S, Naehrlich L, Sermet-Gaudelus I, Southern KW: Impact of COVID-19 on people with cystic fibrosis. Lancet Respir Med 2020, 8(5):e35-e36.

198. Peckham D, McDermott MF, Savic S, Mehta A: COVID-19 meets Cystic Fibrosis: for better or worse? Genes Immun 2020, 21(4):260-262.

199. COVID-19 and The Paget's Association [https://paget.org.uk/news-events/covid-19-coronavirus-and-pagetsassociation\#: :text=A., should\%20you\%20have\%20the\%20virus]

200. Waller R, Price, E., Carty, S., Ahmed, A., \& Collins, D. : EP01 Post COVID-19 reactive arthritis. . Rheumatology Advances in Practice 2020, 4(Suppl 1). 